Portland State University

PDXScholar

\title{
A study of two attempts by President Plutarco Elias Calles to establish a national church in Mexico
}

Roger David Gouran

Portland State University

Follow this and additional works at: https://pdxscholar.library.pdx.edu/open_access_etds

Part of the History of Religion Commons, and the Latin American Studies Commons Let us know how access to this document benefits you.

\section{Recommended Citation}

Gouran, Roger David, "A study of two attempts by President Plutarco Elías Calles to establish a national church in Mexico" (1995). Dissertations and Theses. Paper 3561.

https://doi.org/10.15760/etd.5443

This Thesis is brought to you for free and open access. It has been accepted for inclusion in Dissertations and Theses by an authorized administrator of PDXScholar. Please contact us if we can make this document more accessible: pdxscholar@pdx.edu. 
THESIS APPROVAL

The abstract and thesis of Roger David Gouran for the Master of Arts in History were presented May 11, 1995, and accepted by the thesis committee and the department.

COMMITTEE APPROVALS:

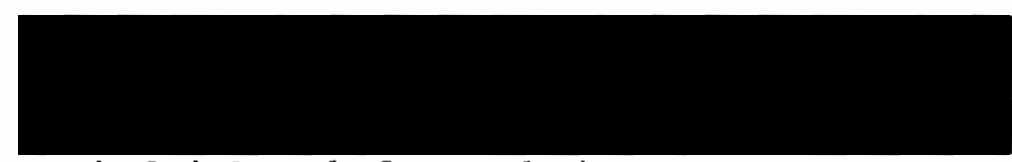

$$
\text { Friedrich Schuler, Chair }
$$

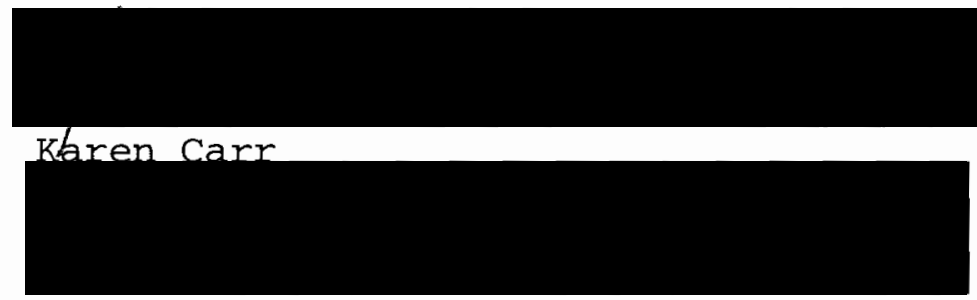

Lawrence Wheeler

Representative of the Office of Graduate studies

DEPARTMENT APPROVAL :

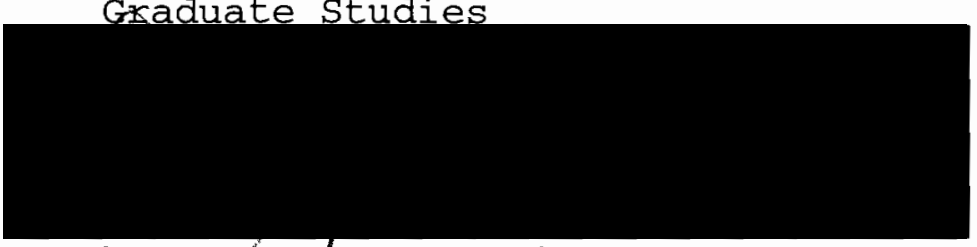

David A. Johdson, Chair
Departmentof History

ACCEPTED FOR PORTLAND STATE UNIVERSITY BY THE LIBRARY

by

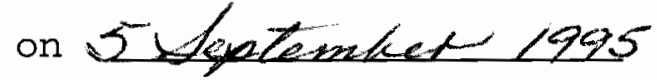


AN ABSTRACT OF THE THESIS OF Roger David Gouran for the Master of Arts in History presented May 11, 1995.

Title: A study of Two Attempts by President Plutarco Elías Calles to Establish a National Church in Mexico.

In the one-hundred years between 1810 and 1926 there were many civil wars in Mexico. The last of these wars. La Cristiada, was not fought, as were the previous civil wars, by groups seeking political control of Mexico. Rather, the genesis of this war was a question of who would control the Church in Mexico. The war began when President Plutarco Elias Calles attempted to enforce rigorously certain articles of the Constitution of 1917 as well as two laws which he promulgated. If Calles had succeeded, he would, in fact, have created a church in Mexico controlled by the federal government.

The material to support this thesis was taken largely from the Mexican legal documents, the writing of Calles, other sources contemporary with the events described and some secondary sources. This thesis stresses the religious reasons for the La Cristiada and discusses the war itself not at all. 


\author{
A STUDY OF TWO ATTEMPTS \\ BY PRESIDENT PLUTARCO ELIAS CALLES \\ TO ESTABLISH A NATIONAL CHURCH IN MEXICO
}

by

ROGER DAVID GOURAN

A thesis submitted in partial fulfillment of the requirements for the degree of

MASTER OF ARTS

in

HISTORY

Portland State University

1995 


\section{DEDICATED}

To

$$
\begin{gathered}
\text { MARC, PHILIP, TRACY, } \\
\text { THEIR NAMESAKES } \\
y \text { más Especialmente } \\
\text { JUNE }
\end{gathered}
$$

To the Former: A token for what I owe them which is more than I can say.

To the Latter: Para Su Paciencia Incrédible. 
TABLE OF CONTENTS

CHAPTER

Page

I INTRODUCTION $\ldots \ldots \ldots \ldots \ldots \ldots \ldots \ldots$

I I PATRONATO REAL............... 8

III EARLY CONSTITUTIONS OF MEXICO....... 18

IV CONSTITUTION OF 1857 AND THE

LAWS OF REFORM.............. 26

V THE MEXICAN CONSTITUTION OF $1917 \ldots \ldots .34$

VI BETWEEN 1917 AND $1924 \ldots \ldots \ldots \ldots \ldots \ldots 5$

VII CALLES THE MAN.............. 72

VIII BURDAR................... 100

IX ASSAULT ON THE SCHOOLS.......... 116

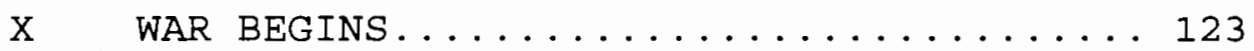

BIBLIOGRAPHY .............. 128 
CHAPTER I

INTRODUCTION

In August of 1926 some communicants of the Roman Catholic Church in Mexico began an open war against the government of General President Plutarco Elias Calles. The cause of this rebellion was that the bishops of Mexico had interdicted all liturgies of the Roman Catholic Church. They had done this to protest the attempts of President Calles to enforce certain articles of the Federal Constitution of Mexico as well as two laws recently promulgated by him, one of which later bore his name.

It is the thesis of this paper that by rigorously enforcing these articles and laws and attacking the Church, Calles was attempting to destroy completely the religious and educational domination of the Roman Catholic Church in Mexico and to substitute for the Roman Catholic Church a Mexican National Church controlled by a secular government. One author explicitly states that it was: "The attempt of a Socialist State to establish a State Church over and above the Church of Christ."1 Put another way: "The origin of the conflict was...

${ }^{1}$ Eduardo Iglesia, S.J. and Rafael Martinez del Campo, S.J.[Aquiles P. Moctezuma], El Conflicto Religioso de 1926: Sus Origenes, su Desarrollo, su Solución. (Mexico City: Editorial Jus, 1960), p. 40. 
to bring into reality the nationalization of the Church."2

Calles first attacked the Church as early as 1915 when, as governor of the state of Sonora, he banished all priests from that state. Later, in February of 1925, as President of the Republic of Mexico, he was instrumental in physically expelling Roman Catholic priests from a state owned church and installing priests of the lately formed Mexican Apostolic Catholic Religion. When Calles' initial attack failed, he began rigorously enforcing those articles of the Constitution of 1917, which were written to circumscribe the activities of the Roman Catholic Church in Mexico, in order to achieve his objective of establishing a National Mexican Church. His special means of creating a national church in Mexico was to be the schools of Mexico. The members of Calles' government were, in their view, trying to bring the people of Mexico from under the thrall of a foreign prince, the Bishop of Rome.

The influence of the Holy see has been strong in the history of Mexico since the time of the Conquest and well into the twentieth century. Some of the earliest Spanish documents concerning what was then called Nueva España deal with the interests of the Spanish Crown and those of the Church as represented by the Pope. ${ }^{3}$ These documents, which will be dealt with in chapter two, describe the various prerogatives of the

ibid., p. 309 .

${ }^{3}$ Charles C. Hale, Mexican Liberalism in the Age of Mora. (New Haven: Yale University Press, 1968) see especially chapter four. 
Church and state and their relationship with each other. This relationship and the exercise of the various prerogatives carried on through the period known at the Patronato Real (1535-1824) during which time the Church accumulated great wealth in both real property and ready cash. She also became the single formal, social institution which has endured throughout the history of Mexico. Her financial and social influence did not end with the demise of Spanish rule in 1824 .

Close ties, not only of a theological nature, but also of a political nature remained between the Catholic Church in Mexico and the Holy see throughout the first half of the nineteen century. In a sense the Patronato had not ended. One form of governance had been substituted for another. The second remained as closely bound to the Church as the first. This will be seen when we examine the first constitutions in chapter three.

This connection led directly to a concerted effort by the nineteenth century Mexican Liberals to break these ties and diminish the influence of the Church followed in the period known as the La Reforma (1845-1862). Thanks to their efforts and the work of President Juárez the wealth and influence of the Church were greatly diminished. In chapter three we shall also see that both the attempts were made not only to diminish the wealth of the Church, but also to end her monopoly in education.

Emperor Maxmiliano in his brief reign (1862-1867) 
reversed some of the work of the Reformers. In the long presidency of Porfirio Diáz (1876-1919), the Church was largely left alone, though the she regained some of her power and wealth. Though influential in many areas, Diáz made no substantial impact on either the Church or education and will not be discussed in this thesis.

The period of the Revolution (1910-1918) was a time of chaos for all Mexicans. The Church was no exception. From the end of the Revolution, however, until a new civil war began in 1926, relations between the Church and the state became increasingly antagonistic. The antagonism began with the creation of the Constitution of 1917 and culminated with La Cristiada. The constitution and the law arising from it are crucial to this thesis and are discussed at length in chapter five. This document is the basis for the antagonisms which arose in Mexico between 1917 and 1925.

The antagonists were the Roman Catholic Church in Mexico represented by the national episcopate and General President Plutarco Elías Calles, the subject of chapter six. His goal was to destroy the armies of the Pope whom he saw as the enemy of progress in Mexico. Nor was this destruction an objective of secondary interest in the General's vision for Mexico. He was simultaneously engaged in a two front war of nationalism. While fighting the Church, he was also in combat with the United States over the question of oil and other mineral rights. Indeed, he saw his two enemies as allied against him. 
Alvaro Obregón, Calles' predecessor warned him against the former battle. We do have ample evidence that the question of religion and therefore the religious war were enough to cause paroxysms of rage within the man. It is not difficult to believe that he wanted to destroy the Church. Even if it required a civil war to do so.

This civil war did not erupt immediately; there was a period of calm. Yet, as pointed out in chapter seven, it was clear that there was discontent with the manner in which the state was dealing with the church.

Chapter eight deals with Calles' direct assault on the Church as his first serious attempt to supplant Her with a national church, a church whose sole political loyalty was to the Republic of Mexico. This attempt failed.

After this failure, Calles then attempted to abolish completely the schools operated by the Roman Catholic Church. In chapter ten we shall see that he promulgates laws which, in effect, do abolish them. A civil war begins and ends in chapter ten. Chapter eleven assesses the results.

By 1926, civil wars were no new event in the Mexican history. One has only to read any account of the history of Mexico in the nineteenth century to realize this. Indeed no less a person than Alvaro obregón referred to what is usually called La Revolucion as a civil war. La Cristiada, however, was unique. Before this war, all Mexican civil wars had been fought between or among contending political powers, 
centralists vs. federalists, conservatives vs.liberals, reformers vs.imperialists. All were attempts by one or more groups to seize power from another. Los Cristeros was a war between a secular power and the communicants of a religious power. The issue was not what party or groups would rule. It was whether the state could tell people how to worship.

As in all wars, there were political and economic aspects to this one. Most of the authors who wrote about this war acknowledge this fact. Of the many fine authors cited in this thesis, and the current author is indebted to all of them, only Quirk mentioned the law of July 2, 1926, and he gave it scant attention. The others were concerned only with political, economic, or military events and movements which preceded or occurred during the rebelition.

They failed to realize that General Plutarco Elías Calles was not simply trying to establish a national church by enforcing specific articles of the constitution of 1917 . He was attempting to do so for two reasons: 1)First, there is no doubt that he genuinely believed that the Roman Catholic Church had done great evil to Mexico. Second, he hated the Roman Catholic Church. He attempted to do so by controlling the education of the children from their earliest years in school. This thesis stresses this fact and the fact that President Calles used the Constitution of 1917 to achieve his goal. The interdiction ordered by the bishops of Mexico was the proximate cause of the war. This war was fought more for 
religious reasons than for economic or political ones. It was a war for, what would be called in a later time, "the hearts and minds of the people." The present work differs from my sources in that it is concerned solely with the religious causes of La Cristiada. Unlike my sources, it does not discuss any political and economic causes of the war. Indeed, the author believes that these were secondary reasons for the fighting.

All of the research for this thesis was done in Mexican archives. I made extensive use of the Archivo General de la Nación and Fideicomismo Archivos Plutarco Elías Calles $y$ Fernando Torreblanca in Mexico City. I should add here a note about translation. Many of the texts quoted in this paper are found only in Spanish. This includes, of course, all the Constitutions and laws quoted herein. All translations into English, therefore, are my own, unless otherwise indicated, and I take full responsibility for their accurate rendering. In most cases I have tried to maintain the exact meaning of the Spanish legal terms without being literal. In some cases, however, it was necessary to use paraphrases since some of the Mexican legal concepts exist neither in Anglo-American jurisprudence nor legal terms.

For texts other than those which deal strictly with legal matters, I tried to bring across the meaning of the author, again, without being literal or wooden.

Querétaro, Querétaro, México

May, 1995 
CHAPTER II

Patronato Real: The State-Church and Its Legacy During the years 1521-1810 the Spanish colony of Nueva España knew one form of governance, the Spanish Crown, and one form of religion, the Roman Catholic Church. The ties between the two institutions were so close that they formed a virtual theocracy. For almost three hundred years the Crown guaranteed the Church many fueros, special privileges. The Church guaranteed to the Crown the tranquility which a single religion would provide throughout the hugh colony and an effort to keep the indigenous populations pacific. In 1810 all of this began to change. By 1824 the old Spanish colony had become the Republic of Mexico. The governance had changed. The Church had not. She wanted to retain Her status and privileges.

During the course of the next one-hundred years, the secular governments of Mexico, beginning with La Reforma, legally took them away. This stripping of power and privilege culminated in specific articles of the Constitution of 1917. It became a crisis when Plutarco Elías Calles attempted to enforce these articles. It is necessary, therefore, to look at the Patronato Real in order to find the origins of Church privileges and power and the laws which were promulgated to destroy them. 
Almost from the time Cortez stepped ashore in the New world, there began to develop between the Roman Catholic Church and the Crown of Spain a modus vivendi which lasted in Nueva España until the Independencia of 1810. Even the date of the landing carried an almost prescient religious significance: Good Friday, April 21, 1519. The concept of a strong, symbiotic union between an established religion and the government was not, however, introduced to Mesoamerica by the spaniards. Such an institution had before already existed before they arrived.

While the individual priest was dedicated to complete poverty, abstinence and celibacy, the church itself was the single richest entity in the Aztec state. Each temple received official revenues and was endowed with estates and the serfs and slaves to work them. The larger temples possessed whole tracts of conquered territories, and every temple shared in the gains from the year's campaigns. In addition the emperor was lavish with gifts from his own purse. The predominance of the priesthood was symbolized by the fact that the temple was always the tallest and most imposing building in any city. When the conquistadores first set eyes on Tenochtitlán [Mexico City] they thought that the two great temples rearing up out of the main square must be the palaces of the ruler. ${ }^{1}$

The fact that the indigenas of the New World were accustomed to a semi-theocratic state was one reason why they accepted a new religion so easily. Another aspect of the indigenous religions should be mentioned here. That is the alfresco nature of their rituals. Because the mass, which can be understood as human sacrifice, can be celebrated as easily out

Jon M. White, Cortes and the Downfall of the Aztec Empire, (New York: Carroll\&Graf, 1971), p. 123 
doors as within a building, this mode of worship was quickly adapted by the Church.

Throughout Mesoamerica there were many temples to the autochthonic gods. And while sacrifices were performed at the temples, worshippers remained outside their precincts. This was to have an influence on the liturgical practices of the Church during its early years in Nueva España. Because churches take some time to construct, masses were frequently celebrated outside. This practice was to continue for many years, and, as we shall see, had a direct influence on the Constitution of $1917 .^{2}$

This union of government and religion among the Aztecs is of uncertain date and origin. On the other hand, we know the date and origin of the union of the Roman Catholic Church and the monarchy of Spain and the extension of that union into Nueva España. Still, it is not easy to fix a date certain for the beginning of the Patronato Real that union of the Crown of Spain and the Triple Tiara of Rome which was to rule Nueva España three hundred years.

Although there have been attempts to show that it began during the Papacy of Alexander VI, 1492-1503, there are no reliable documents dated before the Papal Bull, Universalis Ecclesaiae, promulgated by Julius II, June 28, 1508 .

${ }^{2}$ Many political movements, beginning with the Independencia, began outside. Article 24 of the 1917 Constitution expressly states that all religious liturgies must be held within church buildings. It is my opinion that this is a means of crowd control. 
This Bull gives to the monarch [of spain] nothing more than the exclusive rights to build churches and to present candidates for installation as bishops to the Pontiff and to grant ecclesiastic benefices to the ordinary. ${ }^{3}$

The phrase "nothing more than" makes it clear that from the beginning, in the eyes Papacy, at any rate, secular authority was to have very little to say about the internal affairs of the Roman Church in Nueva España. Indeed, the areas of royal influence were spelled out quite clearly. The Crown, however, had different ideas.

Felipe II, one of the Spanish monarchs most jealous of his royal prerogatives and rights, said in 1565:"By right, ancient custom, just title and apostolic_concession we are the Patron of all the Churches cathedrals and of its royal lands, and to Us belongs the nomination of archbishops, bishops, and the priors and abbots of monasteries of all the these royal lands although they live in the court of Rome." 4

Yet Felipe was also to say:

It is a certain and certified obligation that Christian kings and princes must obey, guard, and perform Christian duty, and in their own kingdoms, states, and domains obey, guard, and fulfill the decrees and mandates of the Holy Mother Church and assist, aid, and show favor in effecting, executing, and conserving them as they are Her sons, protectors, and defenders. ${ }^{5}$

Thus, from the very beginning there was conflict between the State and the Church in Nueva España. One reason for the intense nature of this conflict was that circumstances

${ }^{3}$ Iglesias, El Conflicto Religioso, 43.

${ }^{4}$ ibid., p. 49.

${ }^{5}$ ibid., p. 50 . 
frequently forced the church to rely on civil authority; and vice-versa.

We have shown both by theological evidence and by canonical rights...that the supreme power in spiritual matters and in the internal polity of the Church did not rest with civil authority, but rather by divine right is the exclusive domain of the Pope. At any rate, as there is no solid reason for condemning civil authority when, at suitable times, it intrusts clergymen with public questions and purely civil matters. In the same manner, there is no cause to reprove the Pontiff when he permits, in appropriate circumstances and in matters which can be delegated by him, some intervention of civil authority in matters ecclesiastical. ${ }^{6}$

In Latin America the boundaries between the authority of the Church and the authority of the state were not clearly drawn. The situation was exacerbated by the fact there were about three thousand miles of distance and months of time separating the Holy See, Spain, and Nueva España. Communication was slow and difficult. Misunderstandings if not outright conflicts of rights and interests were bound to arise. And they did. Who then was to decide between the conflicting claims and interests of Church and State when there was no disinterested party? This question from the sixteenth century foreshadows the same question in the twentieth. This question remained unanswered even after Mexico became an independent nation. And it is one which arose in again 1917.

Despite this conflict, the Roman Catholic Church was to be the dominant social and financial institution in Nueva España for the next three hundred years. She was in fact the

6ibid., p. 47. 
"established church" both in the sense that she was the only church, and in the sense that the state enforced Her laws.

In the colonial era, Church and state were one, joined by the Patronato Real...The Spanish government enforced the collection of the diezmo, or ecclesiastical tithe, like any other tax, and monastic vows, once taken, were binding under civil as well as canon law. A monk or nun who dared leave the claustral life could be hunted down like a common felon....

Nueva España was a vast colony with a widely scattered population. The Church was present in almost every small village and certainly in every large town. The priest, because of his holy office was a man of stature, one whom the people frequently heeded even in matters non-ecclesiastic. The Church was a very cohesive social force. She had also accumulated, in addition to Her vast holdings in real estate, large amounts of ready cash. She became the chief money lender of the colony. These are two facts with which the framers of the later political constitutions, especially the Reforma, of Mexico were forced to deal. It was, in fact, to be a very long time before the conflict concerning the property and wealth of the Church was to be resolved. If, indeed, it has yet been resolved. ${ }^{8}$

It was during these three centuries of religious and

${ }^{7}$ Robert E. Quirk, The Mexican revolution and the Catholic Church, (Bloomington and London: University of Indiana Press, 1973), p. 7 .

${ }^{8}$ After research had begun for this paper, the principal articles of the Constitution which are relevant to my subject were amended. Though these amendments do not bear directly on this thesis, they will be discussed in a later chapter. 
social hegemony that the Church in Nueva España not only accumulated vast wealth but also the political "clout" which accompanies such wealth. She also acquired the selfishness and corruption which accompanies great wealth. This is not to say that every churchman in Nueva España was a corrupt and worldly degenerate on rather much the same level as the secular authorities, though that case has often been correctly made that many clergymen were. As we shall see, the Liberals of La Reforma framers of the Constitution of 1917 certainly believed that they were, and they wrote their documents with such stereotypes firmly convicted in their minds. Indeed, it was their conviction that the Church, sanctioned by the state, had caused most of the civil and secular ills of Mexico. It was, therefore, the responsibility of the new state to remedy those ills. The situation was, in reality, more complex than that.

In addition to using Her position to increase Her wealth, the church also used some of that wealth in charitable and educational works. She provided the only schools and medical care to the innumerable indigent. This was due to the reciprocity between the state and the Church. The Crown, for its part, allowed the Roman Catholic Church a great deal of freedom and latitude. She could acquire great wealth, either through the various monastic orders or through the sundry bishops. Rome could also appoint men to the bishoprics and other high clerical positions. The Crown, however, could veto appointments. The monarchy, after all had, at least as much 
economic interest in Nueva España as did the Church and wanted to make sure that prelates were politically loyal. In addition, the Church had certain fueros, perquisites: Under the jurisdiction of the Crown Her property could not be confiscated nor could Her clergy be tried in secular courts. In short, the Church in Nueva España in 1810 was living with the same feudal arrangements she had enjoyed in spain for centuries past, but which other European countries had long since abolished.

Felipe, the secular authority, had claimed the right to control the lands and buildings of the church as well as the right to nominate clergy. The framers of the Constitution of 1917 claimed much the same rights for their state. And if the secular state of Felipe could grant to the clergy immunity from trial in secular courts, then the state of 1917 could certainly deny that same immunity. The state of 1917 was, in practical terms, attempting to resurrect the Church as it had existed in the Patronato Real. There was one major difference, however, between what had existed in Nueva España and what the Revolutionaries wanted to exist in Mexico after 1917. While Felipe was willing to accede in his duty to assist the Church in many ways, the men of 1917 made no such concessions. Finally, the authority to which each side appealed was the principal cause of the conflict in the sixteenth century and of La Cristiada in the twentieth.

But both Church and state shared another common goal, one 
beyond simply increasing their wealth. Each was interested in converting souls to Christianity, specifically Christianity as practiced by the spaniards. It must be remembered that of all the European countries in which the Roman Catholic Church had once been a dominant force, spain alone had not experienced a Reformation. Indeed, one of the moving forces of the counter Reformation, the Jesuits, was founded by Spaniards. Thus, also Nueva España was touched by the Reformation not at all. That was not true of the Inquisition. The pernicious work of that institution was being carried on as late as the time of the movement for political independence from spain begun by Padre Hidalgo in 1810. And it was for political independence from Spain that Hidalgo, Allende, Morelos, et al. were fighting, not religious independence from Rome. The "Grito of Hidalgo", whatever its actual contents may have been, was no more antiChurch than was the American Declaration of Independence. A Catholic Church independent of Rome was completely alien to the thinking of a majority of the first Mexican nationalists ${ }^{9}$. The first political documents produced by them, at least in certain aspects, were sufficiently theocratic to satisfy any claims by the vatican to its right to control secular as well

${ }^{9}$ These were persons born in New Spain whose families had never married with persons from the indigenous populations. In one sense they were truly Spaniards. These Criollos, as they were called, were Spaniards, however, who were never considered to be the political and social equals of the peninsulares who were sent by the Spanish Crown to rule Nueva España. They were expected, however, and did in fact, maintain the Catholic faith. 
as religious matters.

To be sure the Crown of Spain had continued to exert Her authority over the church in some areas. Two incidents illustrate this: They were the expulsion of the Jesuits in 1767 and the cancellation of the clerical fuero exempting priests from trial by civil courts. Meyer says of this:

The important thing is that what took place was a rupture between the government and the governed; this left the masses 'disposable' [sic] and ready to support a government of subversion (1810), which was, in fact, to be mobilized by priests. ${ }^{10}$

It is her break with her political past, the change from Nueva España into the Estados Unidos Mexicanos, which also precipitated the first serious attempt by some Mexicans to break with their religious past.

These attempts, however, were not simultaneous with a political rupture between Spain and her colony. Nor were they, in the beginning, a serious threat to the Roman Church. The latter took place within a span of twelve years. The former developed over a span of fifty. As we shall see in chapter three, the ties between the Roman Catholic Church and the newly independent Estados Unidos Mexicanos, as written into her early constitutions, were probably closer, if that is possible, than those between Rome and Nueva España.

${ }^{10} \mathrm{Jean}$ Meyer, La Cristiada, 3 vols. (Mexico: Siglo Veintinuno Editores, 1973), p. 3 . 


\section{CHAPTER III}

THE EARLY CONSTITUTIONS: $1814-1836$

By the year 1810, the year the citizens of Nueva España began their struggle for independence from Spain, the legal link between the Roman Catholic Church and the Crown of Spain was so strong and so old that it was impossible for most people living in that vast colony to imagine a secular government which did not support the Church. In many minds there was no dichotomy; there was no Church and state. For practical purposes, they were one. Indeed, the constitutions of Mexico discussed in this chapter, though nominally republican, gave legal status to only one church, the Roman Catholic Church, and Her attendant institutions. Since the beginning of the republic the Church continued legally to enjoy fueros ${ }^{1}$, the persons who wished to strip her of these privileges had to sunder the unity by means of a new constitution. In order to understand the Constitution of 1857 and thereby the Constitution of 1917, therefore, one must understand the legal status of the Church under the first constitutions of Mexico.

'The Spanish word fueros as used in this context means certain privileges and prerogatives granted to the Church by the Crown. Examples are that priests could not be tried for secular crimes in secular crimes, they were exempt from military service and taxes, as were all properties owned by the Church. 
In the early morning hours of september 16, 1810, in the small village which is today called Dolores Hidalgo, Mexico, Miguel Hidalgo Costilla, a Criollo and a Roman Catholic priest, supported by an unknown number of indigenas, began the military phase of a political movement which culminated in the independence and subsequent founding of the Republic of Mexico. The avowed purpose of the Criollos who led this rebellion was to sever political ties with Spain. Though the Inquisition declared them heretics for their revolutionary activities, they did not break with the Rome, as did Martin Luther, for either political or theological reasons. Indeed, Hidalgo's first act as leader of the revolutionary army was to seize the banner of The Holy Virgin of Guadalupe from the nearby church at Atotonilco as the flag under which his army was to march. And Morélos, another early hero of the Independencia, proposed that the Pope be mentioned in Mexico's first constitution. Thus, as the colony of Nueva España had begun with a union of Church and state, so also began the Republic of Mexico.

That the rebellion of 1810 was political and religious, not theological, is made clear by three facts. The first is that

In order to accentuate the religious character of this vigorous, popular rebellion it must at the same time be taken into account that the principal leaders were priests, pastors of the people, in whom the people saw the honest personification of religion. They were rebelling against the bishops and prelates because they saw injustice on all sides, because the parishes and the churches were 
the only refuges for the indians.

The higher clergy, the primates, were with the Spanish; the lower clergy, the humble priests, were with the indians. It was this split which gave religious character to the insurgency. This split begins with the conquest; it was the battle between the Catholicism of Cortes and the Catholicism of the missionaries. ${ }^{2}$

Nowhere in the words or works of the leaders of the insurrection is there any indication of ill-feeling toward the Roman Catholic Church as a spiritual or theological institution. In fact, the ostensible reason given for the timing of the rebellion was that two years earlier, 1808, Napoleon had placed his brother on the throne of spain. The people of Mexico had no loyalty to the puppet usurper. The rebellion, therefore, could be regarded as patriotic. The Criollos and the indigenas were being loyal to Ferdinand VII, the hereditary King of Spain.

Second, the rebels chose the banner of the Holy Virgin of Guadalupe as the standard under which they were to fight. And while there are no authentic records of the events of the first few hours or days of the revolt, according to one historian following the example of Thucydides,

Hidalgo presented himself in the door of the church [at Atotonilco] waving a standard suspended on the tip of a lance. On the white linen banner had been painted the image of the Virgin of Guadalupe. Hidalgo shouted to the crowd in a loud voice: "Long live our Holy Mother of Guadalupe! Long live

'Jesus R. Flores, Don Miguel y Costailla: Padre de la Independencia Mexicana (México: Editions Botas, 1953), p.129. 
Ferdinand VII. Long live America!" ${ }^{3}$

Considering subsequent events, the sentiments expressed, if not the words themselves, are accurate.

The third reason, is the theocratic concept of government which was written into the early constitutions of Mexico. The idea that Mexico was to be a theocracy or at least a country with a single national religion was to remain part of her constitution until La Reforma when it was abolished. But only for a time. It was revived under the Emperor Maximiliano." The third can be more easily documented than the first two, and the documents speak for themselves. Among these are proposals to be included in a constitution. The first is by Ignacio López Rayón, an early successor to Hidalgo: Art.1 "The religion [of Mexico] will be Catholic and no other will be allowed." Art. 3 "Her dogma will be upheld by the Tribunal of the Faith [the Inquisition]. ${ }^{5}$ Morelos who, like Hidalgo, was a priest, echoed these sentiments: "The dogma will be upheld by the hierarchy of the Church who are

${ }^{3}$ ibid., p. 128.

${ }^{4}$ Mexico did not constitutionally rid herself of this concept, in fact, until 1917.

${ }^{5}$ Felipe T. Ramirez. Leyes Fundamentales de México 1808-1987. (México: Editorial Porrúa, 198), p. 23. Throughout this paper I have used Ramirez's excellent book as my source for the definitive forms of the various Mexican Constitutions. All direct quotations from a particular Constitution are taken from him unless otherwise noted. He is the only source I found which contains all the Mexican Constituions. 
the Pope, the bishops, and the priests." 6

The first authentic constitution of Mexico was the Constitution of Apatzingán and is dated October 22, 1814. This document never carried any real force because it was promulgated during the war for independence and there was no government strong enough to enforce it. It is indicative, however, of the thoughts of the persons who were attempting to supplant the spaniards as political rulers regarding the relationship between Church and state.

Article 1: The Roman Catholic and Apostolic religion is the only one which can be professed in this Nation.

Article 4: The religion of the Mexican Nation is and perpetually will be Roman Catholic and Apostolic. The nation will protect Her by reasonable and just laws and prohibit the exercise of any other religion.

Article 14: This nation establishes that foreigners who profess the Roman Catholic Religion and do not oppose the liberty of this nation will also be regarded as citizens.

Article 15: The status of citizen will be lost for the crimes of heresy, apostasy, and encouraging them .

And in order to take one's position in the congress, an affirmative answer to the following question was required: "Do you swear to defend at the cost of your blood the Apostolic and Roman Catholic Religion.?" The Constitution of 1824 repeats many of the same laws. Article Four in the 1814 Constitution, for example, becomes Article Three in 1824. 
Qualifications for citizenship are not mentioned. Fueros were continued for clergymen and soldiers in Article 154: "Soldiers and clergymen will remain under the same authority to which they are subject under the current laws." Fueros were a custom left from medieval times under which, among other things, soldiers and clergymen could be tried for crimes, civil or otherwise, only by ecclesiastical or military tribunals.

There is another aspect of both the Constitution of 1824 and of 1836: The preambles of both are invocations. "In the name of Almighty God, Author and supreme Legislator of society." ('24) "In the name of Almighty God, three and one, by whom men were destined to form societies and conserve those which they form." ('36) There were some additions to the Constitution of 1836 .

Under Article 3, for example, Mexicans are obliged, "...to profess the religion of their fatherland..." Article 45, which limits the power of the Congress, adds a further protection for the Church. The General Congress shall not have the power "To deprive either directly or indirectly any individual of his property whether he be a private person, or a corporation, ecclesiastical or secular." This article, which was to be changed drastically in a later constitution, shows clearly that in matter of property the rights of the Church were held to be superior to those of the state. ${ }^{7}$

${ }^{7}$ Alicia Olivero Sedano, Aspectos del Conflicto Religioso de 1926 a 1929: Sus Antecendentes y Consequencias. (México: Secretaría Educación Püblica, 1987), p. 87. There is, perhaps, 
Like its predecessors, the Constitution of 1836 lived for only a short time, for within a decade the era known as La Reforma began. The political thinkers and politicians of this era through their writings and confrontational debates set the standard for all subsequent political philosophy in Mexico. And it was in this era, the era of Benito Juárez and the Emperor Maxmiliano, that both the Conservative and Liberal movements of Mexican history arose. And it was also in this era that the economic and political influence of the Roman Catholic Church in Mexico, if not completely shattered, was greatly diminished.

Almost from the time of Hidalgo himself there had been some sentiment within Mexico for a national church. Sedano states that the idea of creating a National Mexican church totally independent from the Church of Rome existed as early as the year 1822. Though the independencia was complete, there was disorganization among the clergy because some of the bishops who had opposed the insurrection were in exile and some had died leaving their dioceses without leaders. ${ }^{8}$ This sentiment for and independence from Rome is probably one reason why the framers of the early constitutions were so emphatic in their declarations that Mexico was and would

another side to this question. Alicia Olivera Sedano suggests that there was, at the time of the Independencia, some sentiment in Mexcio for creating a Catholic Church independent of Rome. We shall look at this later.

${ }^{8}$ Sedano, Aspecto del Conflicto, p. 87. 
remain Roman Catholic. There would have been no need to legislate loyalty to Rome if their had been no threat to that loyalty.

This fact must be kept in mind because the idea of a purely Mexican Church with neither political nor financial ties to Rome is one which reoccurs throughout Mexican history generally and in the regime of President Plutarco Elías Calles (1925-1929) particularly. 
CHAPTER IV

THE LAWS OF REFORM AND THE CONSTITUTION OF 1857

The Constitution of 1857, as have all the constitutions of Mexico, established the jurisdiction of the Federal Government over many areas of society. There are only two of these areas and their concomitant laws which are pertinent to this paper: the laws governing education and the laws governing religion, particularly the laws governing the prerogatives and perquisites of the Roman Catholic Church in Mexico. The Laws of Reform which were promulgated at a later date were, in almost all respects, a logical extension of constitutional articles. To the man who promulgated them, Benito Juárez, they were more than mere extensions. They were, in his view, absolutely necessary for the well-being of Mexico. So necessary, in fact, that they were not laws at all in the usual sense of the word; they went through no legislative process. Rather, they were decrees issued by Juárez during his tenure as President of the Republic. They are important to this paper since they provided the legal precedents for subsequent acts written into the Constitution of 1917. These were the laws which Plutarco Elias Calles was so determined to enforce.

In The Constitution of 1857, the fifth constitution of Mexico, the Federal Government legislated for the first time 
in two areas with which it had not previously concerned itself at all: education and labor. It would not be the last time.

Art 3. Education is free. The law will determine the qualifications necessary for its licensure and what requirements will be demanded.

Art 5. No person is obliged to render his personal labor without just compensation and without his complete consent. The law does not recognize as valid any contract which has as its purpose the loss or irrevocable sacrifice of the liberty of a man whether it be for the cause of work or education or a religious vow....

The document elaborates no further on either Article 3 or Article 5. The framers of these articles did not specify, for example, how public education was to be funded in Mexico. Though Federal financing could be inferred, they may well have thought that the states would pay the bill. No matter how schools were to be financed, Article 3 made it clear that the Church was no longer to be the sole educator in Mexico, a task She had been performing for some three hundred years. Article 5 is another matter.

Like Article 3 it is clearly directed against the Church, specifically Her religious orders. But it goes even further, for it directly attacks monasticism which had been an integral aspect of the Roman Catholic Church, one which had been a stable institution within Her purview for about fifteen hundred years. The reason for this article has little do with the question of involuntary servitude. Article 2 outlawed slavery and automatically freed slaves brought into Mexican territory. Since taking religious vows is presumed to be a 
voluntary act, such a vow could not be construed as placing oneself in a state of slavery. The reason lay elsewhere. During the three-hundred years she had been in Mexico, the Church and Her associated religious orders had grown rich and powerful because, in many of their enterprises, they did not have to pay a work force. The vows of poverty and obedience precluded that. Furthermore, it was customary for all persons entering the clergy or the monastic orders to sign over to their respective superiors all their real property and any other forms of wealth they may have possessed or would inherit. In addition, it was expected that the scions and daughters of wealthy families would often be accompanied into their religious life by a substantial gift of land or money from their families. Since such wealth, once it became the property of the Church, could no longer be taxed, the state stood to gain considerable income because all such property would now remain in secular hands. Because it was a ready source of cash, the Church had also become the major creditor in Mexico by the middle of the nineteenth century. ${ }^{1}$ There was a further consequence.

The state, by declaring itself the propagator and supervisor of education and by obtruding itself in to what had heretofore been strictly a matter of religion and individual conscience, established itself as an entity totally separated

${ }^{1}$ David C. Bailey. Viva Cristo Rey: The Cristero Rebellion and the Church-State Conflict in Mexico. (Austin and London: University of Texas Press, 1974), p. 5. 
from the Church, yet controlling Her activities in specified areas. Article 5 makes it clear that the state will control the schools. It will decide what is to be taught and who will teach it. With the advent of the Constitution of 1857 the Real Patronato ended. The state and the Church were separated for the first time since Cortez. At least legally so. Yet other laws were required before the schism could be complete. The Laws of Reform fulfilled the requirements, for they stripped the Church of most of Her influence in areas which the state considered itself supreme. Ironically, to disestablish the Church in Mexico Juárez used the same arguments to which the kings of Spain had used to establish Her in Nueva España. He, as they, was doing only what he believed was good for the State. These decrees and the Constitution of 1857 constitute La Reforma.

There were nine of these presidential decrees, all published between July 12, 1859, and February 26, 1863, and which deal with various aspects of Mexican society. Taken in chronological order they are:

1. The law nationalizing all ecclesiastical property and suppressing all male religious orders.

2. The law of civil matrimony.

3. The constitutional law of civil registry.

4 The law of the civil justices.

5. The law giving control of burial places to the State.

6. The decree of official holidays.

7. The law concerning religious liberty.

8. The law secularizing eleemosynary institutions.

9. The law abolishing communal religious communities.

singly and collectively they were at once a bald attempt on 
the part of Juárez both to deprive the Church of Her vast holdings in Mexico and to end Her control and influence in areas which he specified as secular and in which he deemed the Church should have neither influence nor control. He makes this point abundantly clear in his preambles to these decrees. of these nine laws, only one, seven, eight, and nine are relevant to this paper. The first law stated directly that all property administered by clergy became the property of the Nation. Article two says that there will be a special law to determine how and in what manner all these properties would be absorbed into the national treasury. In addition, all religious orders were abolished and the wearing of religious habits prohibited. All priests who did not oppose the law would be given a one time payment of five-hundred pesos. If, however, they did not accept the offer within five days of the date of the law, they were ineligible to receive the payment at all. Furthermore, if they continued to live the communal religious life they would be expelled from the country. To further weaken the financial structure of the Church, all gifts pledged by persons who had entered religious order had to be returned.

The seventh law states:

Article 1. The laws will protect the exercise of the Catholic religion and any others established in the country as the expression and result of religious liberty, which, being a natural right of man, can have no restraints placed upon it other than the rights of arbitration and requirements of public order. In every other case, the independence of the state for its part, and of religious beliefs 
and practices on the other shall be complete and inviolable.

This law illustrates two aspects of the man who promulgated it.

The first was the influence of the Enlightenment on the Mexican intelligentsia of the nineteenth century. The idea of the natural rights of man was the foundation for much of their political and economic thinking. ${ }^{2}$ The second is that it was possible for churches other than Roman Catholic to establish themselves in Mexico.

The ninth law was a logical extension of the first, for, like the first it abolished female religious communal orders and confiscated their property. With this law, the state legally dominated the Church completely.

There are three aspects of the Constitution of 1857 and the Laws of Reform which must be noted here. The first is that nowhere in any of the laws pertaining to religion did reformers indicate even a desire to alter either the liturgy or the theology of the Roman Catholic Church. (One suspects these men knew or cared little about these areas in any other Christian denomination.) Yet as will be shown below, there was a desire on the part of many of them to break with Rome. The Reformers looked on this break as a political break, not a religious or theological one.

The second aspect is that the state had decided that it 
too should have a hand in educating youngsters. Article 3 of the Constitution neither specified a curriculum for the schools nor required attendance. What it did do was set the legal precedent that the state should and has a right to oversee the education of its young citizens. One is forced to point out the ironic fact that the many of the authors of this article, including Juárez had been educated in Church schools.

The third aspect is that the state had effectively confiscated almost all of the wealth of the Church; had set barriers to Her acquiring more; and had made it very difficult for males and impossible for females to practice traditional forms of religious life within the Catholic Church.

These, the second and third aspects, when translated into the Constitution of 1917 and extended, were to become, along with other later legislation and decrees, the legal means by which Plutarco Elías Calles hoped to supplant the Roman Catholic Church in Mexico with a National Church, a Church regulated and controlled by the state.

Later, yet still during the Period of Reform, there was a more organized attempt to create a schismatic church which was to be called simply the Mexican Church. This church would devote itself completely to the laws of the Reforma for which service the Secretaría de Gobernación proposed that the priests of this church be paid three-hundred pesos monthly.

${ }^{3}$ This office is roughly equivalent to the office of secretary of the Interior in the United States. A major difference is that in Mexico Gobernación controls the churches. 
The head of this group of schismatics was to be called "Jefe Supremo." This title can be translated in several ways. The word jefe is regularly used to denote a secular political leader. There were other attempts to supplant Roman clergy with priests who had been approved by the state.

In 1868 Juárez, in turn, tried this tactic, and approached the American Episcopalians with a request that they provide the Mexican Church with a bishop....

They turned him down.

Two later attempts to achieve the same goal should be mentioned here. One was by Venustiano Carranzza as First Chief, the other by Plutarco Elías Calles as President.

${ }^{4}$ Meyer, La Cristiada, p. 25. 


\section{CHAPTER V \\ CONSTITUTION OF 1917}

The promulgation of the Constitution of 1917, as many other events in the history of Mexico, attempts to be both a culmination and $a$ beginning. Its full and formal title indicates this: Constitución Política de los Estados Unidos Mexicanos que reforma la del 5 de febrero de 1857. By its framers this document was regarded as the fulfillment, the logical conclusion, of the works which had been begun in $\mathrm{La}$ Reforma. It was to complete in Mexico the work begun in the Enlightenment. Indeed, the term "natural rights" was used very frequently in the Diario de los Debates and the regular form for addressing a delegate was ciudadano, citizen. The articles concerning religion and education are another indication of this. These articles place both education and religion under the direct control of the federal government. These same articles are the ones which Calles used in his attempt to supplant the Roman Catholic Church.

This latest constitution was intended to be a document for stabilizing a nation which had recently been, and by some reckonings in 1917 was still, embroiled in a civil war. Emiliano Zapata had not yet been assassinated and his forces in the south, still strong, had not yet been pacified. Pancho Villa and his troops were still active in the north. Witness 
the raid on Columbus, New Mexico, in March, 1916. Amidst this tumult the Constitution was to lead Mexico into a prosperous and peaceful future. The plan for this "new order of things" was Socialism. Even a cursory reading of this constitution leaves little doubt that it was founded on the concepts of Socialism. Marxist ideas were to be the guide for the future. Nor did any of the leaders deny this. Calles was later to say that being called a Bolshevik was an honor.

This thesis will not attempt to adumbrate nor detail either of these facets except for those specific articles which deal with the relationship of Church and state and which President Calles was determined to enforce. These are articles $3,4,5,24,27,33,130$. In addition, there are two laws, both promulgated in the summer of 1926 during the regime of General President Plutarco Elías Calles which attack directly both the Church and Her schools, and by which Calles both could have and in fact did intend to minimize, if not actually destroy, the political and spiritual influence of the Roman Catholic Church in Mexico. As was shown earlier, the financial influence of the Church had largely been destroyed by the Laws of Reform. To reach his intended goal, it remained for Calles only to enforce those sections of the Constitution of 1917, as executed through appropriate laws, which would circumscribe, proscribe, if not actually destroy, the ability of clergymen to perform duties necessary to their vocation.

Plutarco Elías Calles, General of the Constitutionalist 
Army (1913-1915), Governor of Sonora (1915-1919), later Sectretaria de Gobernación (1921-1925), and finally the President of the Republic (1925-1929), was not among these delegates. He had no direct influence in fashioning the any of the anti-religion articles which he was later to rigorously enforce. Yet there is no doubt that he agreed completely with both the spirit and the letter of these articles and he felt it his constitutional duty to enforce them. As we shall see, he candidly told a delegation of bishops exactly that.

In order to understand how Calles planned to reach his objective and how he mounted his attack, it is necessary to discuss first the relevant articles of the constitution; then the enabling laws which allowed the articles to be enforced. The first of these laws, the "Calles Law" as it was later to be called, was an enabling act for articles already in the constitution. The second law was nothing more than a clear attempt to destroy completely the Roman Catholic elementary schools in Mexico.

It is certain that one could write an entire history of Mexico from the point of view of State-Church relations. It is also clear that from the time of La Reforma, if not earlier, these relations had been strained by both the Church and the State. The Church had attempted to retain Her fueros. The State had denied Her this demand and seized property in the bargain. At the time of the Constitutional Convention of 1917 in Querétaro, a majority of the delegates who wrote that 
constitution, an amended form of which is still the law of the land in Mexico, held anti-clerical and anti-church feelings which were as strong as any held by Calles. One can see this from even a cursory reading of the minutes of their meetings. One can also determine the intent of the various articles from the language in the records and diaries of the debates which preceded their adoption. Calles agreed completely with both the intent and the letter of the articles he attempted to enforce, though he had no direct hand in writing them. The original wording of each article is equally clear since the original articles have also been preserved. It is unnecessary to give the exact wording of each of the relevant articles, the intent and meaning of which can be made clear through paraphrase. The original form of nuestra Carta Magna, as Mexicans are fond of calling this document, the one enforced by Calles, will provide the text for the paraphrase. Before one regards individual articles of the Constitución Politica, one must consider some of its salient features.

The first is that it is a very lengthy document containing one-hundred and thirty-five articles printed in one-hundred and twenty-six printed pages. Furthermore, it is not a document which merely sets up a form of government. Its articles cover subjects ranging from who is a Mexican citizen to marriage to describing who can own land and who is qualified for the professions. Furthermore, it was not promulgated to join together states which were once 
independent political entities. Nueva España was never any sort of confederation. It was one hugh colony. It is logical, therefore, that when Mexico defined herself as a nation, she wrote laws for the entire new nation. It is the federal constitution which both defines the states and grants powers to them, not the states which grant powers to the federal government. The men who created modern Mexico realized this.

It is well known that in the territory bordering our northern frontier there existed several colonies ruled by charters which had been granted to each one individually by the British Crown. For this reason they were positively separate states. Now, having separated from the mother country, they agreed to unite with each other, first in the form of a confederation. Later they formed a federation, a republic. Thus constituted it naturally took the name of the United States.

our fatherland, on the contrary, was one single colony ruled by the same law, one which was governing even those regions which then were not under the authority of the viceroy of New Spain, but which now form an integrated part of the nation.Places like Yucatan and Chiapas. The Constitution of 1824 formed them granting them independent organization. [italics mine] ${ }^{1}$

Thus, the Federal government maintained complete control over the state governments. In fact, as will be seen, President Calles ordered the individual states to enforce the articles and laws governing the Church, even though it is the federal law which defines the relationship between the Church and the State in Mexico and controls this relationship. These were laws written by men, many of whom, were very much opposed to 
religion in any form. This fact will become more evident as the various articles are discussed and various delegates quoted. Here, however, are a few examples: Throughout the debates the word fanatismo is used as a synonym, racional and científico as antonyms, for religion. In the debates Citizen Terrones speaks of a "cancer which destroys the minds of men. That cancer is all religions of whatever sort they may be."2 It is through such sentiments expressed in the debates that one comes to understand the bases for some of the articles.

Many of these articles were, to a very great extent, the work of one man. In the early days of the constitutional convention a "projected" and in many ways complete constitution written by Venustiano Carranza, Primier Jefe Constitionalista, was presented to the delegates. The document finally ratified by the convention was by no means identical with the original constitution projected by Carranza. It was, however, similar. It was especially similar in the articles which will be discussed in this paper. That Carranza was able to do this is not surprising, since as the strongest military, and therefore political, leader in Mexico at the time, Carranza had picked most of the constitutional delegates. Curiously, it seems to this writer, he had not chosen Calles. The first of the articles to be examined is number three. Article 3. Education is free. But it will be secular and under the control of legal officials of 
education. There will be the same requirement for primary, secondary, and higher education taught in private schools. No religious organization nor minister of any church will be able to establish or direct primary schools. Private primary schools can be established only under the jurisdiction of the state. In such legally established schools primary education will be given without charge. ${ }^{3}$

The words above, today translated as private schools, in Spanish escuelas particulares, referred originally to church schools.

The final sentence of this article is worth noting carefully. The men who wrote and ratified this article held three convictions about primary education. The first is that it should be funded by the state. The second is that education through the primary level shall be at least available to, if not required of, all children. "During every period of history and in every country it has been declared primary education is the most efficacious means by which to civilize the people." ${ }^{4}$ The third is that the clergy of the Roman Catholic Church should have absolutely no influence in educating the youngsters of Mexico.

In the history of our country, when studied impartially, the clergy appears as the most cruel and tenacious enemy of our liberties. Its doctrine has been and still is: the interests of the Church

${ }^{3}$ Diarios. All quotations from the Constitution of 1917 as it was originally ratified are taken from this source, and all references to that constitution are from the original form unless otherwise noted.

${ }^{4}$ Felix I. Palavicini. Historia de las Constitución de 1917, 2 vols. (México: Gobierno del Estado de Querétaro, 1987), 1:223. 
before the interests of the fatherland. ${ }^{5}$

Religious education, which contains the explanation of very abstract ideas, ideas which the intelligence of the child is not able to assimilate. That education is detrimental to the natural psychological development of the child and tends to produce a certain deformation of his spirit similar to the physical deformation which is produced by a vicious gymnastic exercise. In consequence, the state ought to proscribe religious education in all primary schools, be they public or private. [underlining mine] ${ }^{\epsilon}$

Citizen Mugica, delegate from Michoacán and one of the most radical men at the convention, wanted to go a step further. He concedes that one may be able to find a very distinguished teacher of mathematics in a religious institution. Removed from this institution he may seem to present no danger.

I believe that he does indeed offer some danger. I fear that because he has lived among clergymen that such a person, be he Protestant or Catholic will take advantage of even the least opportunity to infiltrate his damned ideas.?

Mugica wanted no one who could have suffered the least taint of religion to be allowed to teach in the public schools. This idea was not formally incorporated into any article of the Constitution, and while it was not part of Article Three, this idea was used by Calles later in Law 22 .

The original text of this Article Three is quoted completely for eight reasons: First, because it is a clear

${ }^{5}$ ibid., p. 222 .

${ }^{6}$ ibid.

7ibid., p. 261. 
link with the Constitution of 1857. It is, in fact, an expansion of article three of that document. Second, it is a clear statement that hence forward all educational institutions below the secondary level will be under the control of the state. A difference between '57 and '17. Third, it effectively takes any primary education out of the hands of the Church. Fourth, it is the special article by which calles was to attempt to end the control which the Church had over education for about four-hundred years. Ending this control would, he was sure, end all the political and spiritual power and influence of the Church. He was equally sure that Mexicans would then turn to a new font of spiritual power. Fifth, taking control of education was the method Calles attempted to employ when his earlier attempt to take direct control of the Church failed. The sixth is that while the article forbids the Church or any of Her religious orders from establishing schools, it does not prohibit religious lay persons from establishing schools which could teach religion or catechism, for that matter, as part of their curriculum. Seventh, the article implies that as long as schools run by religious lay persons meet educational criteria established by the state, they could operate. Eighth, it also implies strongly that if such schools are sanctioned by the state, the education received there will be regarded as equal to that of any other schools. The last three points we shall regard more carefully later in the text. 
Article 4, while it does not mention nor deal with religion specifically, was to have a great affect on the Church. The second paragraph of this article says that each state will define what the professions are and determine the qualifications for each profession. The power of licensure rests with the state, a secular power. For most professions this is logical and sensible and on the face of it should present no problems for the Roman Catholic Church or any other denomination. That is until one reads article 130.

This article contains sixteen sections, fourteen of which deal directly with the relationship of Church to state and are explicit statements of the authority of the latter over the former, and limit the areas in which a church of any denomination may act. Because this article involves many areas of religious activity, I shall have occasion to cite it often. Here it is the first, second, sixth, seventh, and eighth paragraphs which concern us. The first section of this article gives the state legal authority over any church in Mexico in certain specified areas.

The federal powers shall exercise the supervision required by law in matters relating to religious worship and outward ecclesiastical forms. Other authorities shall act as auxiliaries of the Federation.

The second section states that the Congress cannot establish or prohibit the establishment of any religion. These are clear enough. A problem for the Church arises in the other sections : 
6) The ministers of the various religions shall be considered as persons who are exercising a profession and they shall be directly subject to the laws enacted about such matters.

7) Only the legislatures of the States shall have the power to determine, according to local necessities, the maximum number of ministers for each denomination.

8) In order to exercise the ministry of any denomination in the United Mexican States, it is necessary to be a Mexican by birth. [italics mine]

These sections restrict severely all the denominations in the practice of their faith. This was what their framers intended them to do.

By defining the vocation of priest or minister as a profession like any other, section six places this profession under the control of the various states, cf. article four. In effect, section four says that secular power shall have the right to dictate who shall legally practice ecclesiastical liturgy and other pastoral duties. There is also implicit in this paragraph the concept that what the states grant to one person, they can deny to another; or, once having granted it to an individual, the state can withdraw it. Section seven is a logical extension of section six.

Since a state can determine who shall and who shall not be allowed to practice sacerdotal tasks, it is also able to determine how many persons are necessary to adequately carry out those tasks. In some states, for example, the ratio of priests to lay person was one per one-hundred thousand. In other states, following the example of Calles himself, the 
government banned all priests. Section eight, which again is a logical extension of six and seven, contains other implications.

The literal meaning of this statute is clear. It is to be taken literally. There is no room for interpretation. Article thirty of the original Constitution of 1917 states emphatically that there are two states of Mexican citizenship: by birth or naturalization. Within a federal law, Article 130, the government of Mexico had established one legal requirement for all clergy practicing their faith in Mexico; that they be Mexican by birth. It allowed the individual states to establish all other requirements for becoming a priest. Thus two secular powers could control all clergy in Mexico. Article 130 goes even further.

Since its inception Christianity has sent clergy born in one culture or nation to others. The history of the Roman Catholic Church in Mexico is prime example of this. In 1917 many of Her priests there had been born elsewhere. Of course, all of them, native born or not, owed a certain allegiance to the Bishop of Rome, a foreign prince. And though the Constitution itself does not speak directly about the Bishop of Rome, the men who debated whether to ratify this article certainly did. The following passages from the Diaries of the Debates of the constitutional convention are representative of the feelings of many of the delegates. Ciudadana Recio evidently did not speak for the majority of the delegates. His 
wish to have auricular confession outlawed in the new constitution did not pass. But he did express their fears concerning the Pope.

[Auricular confession] is one of the greatest acts of immorality. It is one of the greatest crimes which has been committed. And we must ask in a vigorous manner and once and for all...that it be abolished. It is through the confessional that the priest is kept appraised of everything which occurs in people's homes. He pulls the strings in the most intimate matters and he manipulates them most marvelously in political and economic matters and in every other field of human activity. ${ }^{8}$

The assertion here is crystal clear: that priests use the confessional as a place to influence the politics of the penitents. Nor do the priest do so of their own volition. Rome is their mentor.

This touches the second point. That the ministers of religion should be married and that they be Mexicans by birth. I do not see what is so bad or difficult about that. How long, gentlemen, are we going to permit minister of the religions of the Mexican Republic to be subjects to the authority of the Prince of Rome. ${ }^{9}$

Prince of Rome was a carefully chosen phrase. It states baldly, as the term the Pope does not, that the Bishop of Rome is regarded as a foreign secular power, not a spiritual authority. He should, therefore, have no influence in the internal affairs of Mexico. Recio goes on to tell why priests must be married.

Then they will not depend on that prince. They will not have that authority or threat over them, but

${ }^{8}$ Diarios, $2: 753$.

${ }^{9}$ ibid. 
they will create a true Mexican Church always following, of course, the catholic religion about which so much has been said. [underlining mine] ${ }^{10}$

This is not the first time in the history of Mexico that the idea of a Mexican national church had come up for discussion. It had occurred in La Reforma. ${ }^{11}$ What should be noted here is that Recio and other delegates appear to be more interested in breaking the political power of the "Prince of Rome" in Mexico than they are in abolishing all liturgical forms of religion. Citizen González Galindo in the same debate and on the same topic says:

Those same Christians, those same Catholics who support auricular confession are in agreement with an earlier practice back in the time of Christ. Then there was only public confession. Later, in order that the great crimes of the Church not cause a scandal, confession became auricular. That thing which [those Catholics] hold as a dogma is not precisely a religious practice, not precisely a dogma [sic] of faith. They receive confession in secret in order that they might conspire against Government and against her republican institutions...I do not want to attack confession because of dogmatic reasons, but because it is a political instrument...Auricular confession lends itself to committing crimes, to conspiring, and for that reason is not like dogma, not like a doctrine, which in this case would have a reason to exist. But in the political sense, understood as an instrument of conspiracy, we must declare it abolished. [underlining mine] ${ }^{12}$

briefly

Later in the debates Citizen Pastrana Jaimes recounts papal intervention in Mexico since 1493. (Of course, there was

${ }^{10}$ ibid.

${ }^{11} \mathrm{Cf}$. chapter III, p.23.

${ }^{12}$ ibid., p. 756. 
little real intervention, that is invasion, by the spaniards until a quarter of a century later.) Throughout his oration Jaimes uses the word papado, papacy. No mere allusions to the secular power of the "Prince of Rome." He speaks "his mind right on." Some examples:

The papacy did not want to recognize the national independence [of Mexico\}. The papacy did not want to recognize the liberal principles which the Constitution of 1824 contains. When Spain wanted to reconquer Mexico, The papacy issued an encyclical in order to empower the bishops to return Mexico to the domination of Ferdinand VII.

The alliances which the Catholic clergy has with the clergy of other nations has caused stronger nations to intervene in the internal affairs of weaker ones. We have even seen that the clergy of the United States united with that of Mexico has a sought the use of armed force to kill our independence and our national autonomy. The study of these historic antecedents has compelled me, gentlemen, to request an addition [to article 129] which states:

"The church buildings which have been or shall be designated for religious observances and shall be the property of the nation shall not be given for rent, use, exploitation, administration, responsibility in any form direct or indirect to ministers of any religion or

cult who recognizes the authority, jurisdiction or dependence or any sovereign or foreign power whether they citizens by birth or persons who have settled here."

I believe it has not escaped the notice of this honorable assembly that it is a matter of utmost importance that it create a truly national church. [italics mine] ${ }^{13}$

Here is clear evidence that among the deputies who were revising the Constitution there were those who felt strongly 
that 1) the Roman Catholic Church was conspiring against the Republic; 2) the confessional was location wherein the conspiring occurred; 3) priests were part of that conspiracy; 4) they were a threat to the Republic because as conspirators they were subjects of a foreign prince; 5) the way to end such conspiring and the influence of that foreign prince was to create a national Mexican church. None of these points made at the constitutional convention are new. They were brought up at this time because some of the delegates saw the convention as the opportunity to write laws which would facilitate the creation of a national church. They failed. Yet these and similar arguments are ones which reoccur when El Presidente Plutarco Elías Calles attempts to enforce articles 3, 4, 5, 24, 27, and 130. we have looked at articles 3, 4, and 130. Let us now turn to articles 5, 24 and 27

Article 5 is designed to limit the ability of the Roman Catholic Church to fill vocations:

The state does not permit that there come into effect any contract, pact, or covenant which has as its purpose the reduction, loss, or irrevocable sacrifice of the liberty of a man whether that be for the cause of labor or education or a religious vow. The law... does not permit the establishment of monastic orders whatever might be their denomination or for whatever purpose they are established.

The Constitution of 1917 itself and the excerpts taken from the Diario de los Debates leave little room for doubting that the men who promulgated that document had, as one of their goals, to limit severely the Roman Catholic Church or to 
rid Mexico of her completely. Certainly some members of the Methodist Episcopal Church believed that to be so. In a letter on the stationary of that denomination the author states that the "evangelicals" have always tried to obey the Laws of the Reforma, of 1874, and the Constitution of 1917.

The articles[sic] 27 of the constitution of 1917 nationalizing the real property of the church affects directly the properties of the evangelical groups. Since the from the beginning the spirit of the laws of the Reforma has been to restrain the Catholic Church in its zeal to interfere in politics and to completely dominate the country, we believe that something should be done to protect the properties of the evangelicals who are, in any case, diametrically opposed to [the Catholic Church]. [underlining mine] ${ }^{14}$

One cannot doubt that there were very strong anticlerical and anti-Catholic feelings among every man of the delegates to the Constitutional Convention. One is not surprised to find them in the Methodist Episcopal Church. All such feelings were probably best summarized in a speech made during La Cristiada by General J.B. Vargas, who was neither a delegate nor, in-so-far-as is known, a member of the Methodist Episcopal Church.

The evil clergy, composed of traitors to the country, and taking orders from a foreign leader who is always conspiring to provoke foreign interventions in Mexico in order to ensure his domination and privileges, is harmful because its mission is to brutalise [sic] the ignorant people so as to exploit it and make it fanatical to the point of idiocy, and deceive it by making out that the clergy are representatives of God, so as to live off the indolent and illiterate masses, which is where the Friar holds sway. It is enough to have

${ }^{14}$ Archivo General de la Nación, 312 (438-I-4). 
some idea of the terrible history of the Inquisition for one to realise [sic] that priests and cassocks reek of prostitution and crime.

Confession is an industry invented to seduce maidens, to win over Catholic ladies and transform fathers and husbands into chaste replicas of saint Joseph...The Pope is a crafty foreigner who accumulates wealth in collaboration with the exploiting Friars who swindle the foolish people for the benefit of a country quite other than their own... Nowadays, if Jesus Christ were to come down, the first thing he would do would be to hang them like rabid dogs. ${ }^{15}$

We shall hear more General Vargas below.

A question arises: Why, since the Constitution had been ratified in 1917, didn't both presidents Carranza, who opposed the articles, and obregón, who certainly approved of these articles attempt to enforce them?

After 1917, religious strife was local and isolated, if occasionally intense. Venustiano Carranza, as President, showed no disposition to badger the Church and did not enforce most of the constitutional provisions on religion. He had never been a partisan of extreme anticlericalism, and, moreover, he had to deal with other problems, foreign and domestic, that he considered vastly more important. Alvaro obregón, who became President in 1920, saw matters in essentially the same light. ${ }^{16}$

Obregón, while he may personally have been opposed to the articles in question, was compelled by circumstances beyond his control to enforce two of them. It was in the regime of Obregón that Roman Catholics began openly to oppose the articles which they found offensive and threatening to their

${ }^{15}$ Meyer, Cristiada, 1:31.

${ }^{16}$ Bailey, Viva Cristo Rey, p. 34. 
faith.

It is from this early opposition that we can date the more strident activities which eventually led to open war. 
CHAPTER VI

1917-1925: CALM BEFORE THE STORM

During the six year period referred to in the title of this chapter, the new constitution of Mexico was tested in several ways. As Secretaría de Gobernación Plutarco Elías Calles was involved in all of them. One of these tests was the affair of $E I$ Cristo Rey. The matter itself was of small moment, but it compelled the federal government to enforce one of the anti-church articles of the constitution.

In the years between 1917 and his inauguration in December of 1924, Calles served in the governments of presidents Carranza and Obregón. Under the latter he held the post of Secretaría de Gobernación, an office similar to that of the Secretary of the Interior in the United States, but with a far broader range of powers. One is the oversight of foreigners and their work in Mexico. Control of church buildings is another one of them. For example, the government now owned all the church buildings in Mexico. The secretaria de Gobernación could and did use them for any purpose he chose. Calles was well aware of the powers of this ministry.

During his tenure as minister three significant events occurred. The first was the assassination of Venustiano Carranza who had done so much to aid Calles' political career. It was he who gave Calles his command in the Constitutionalist 
army and appointed him governor of Sonora. Other than words issued for publication, Calles seems to have recorded nothing concerning his own feelings about the assassination.

The second was, viewed from the perspective of the hierarchy of the Church, a religious movement instituted and controlled by laymen. Viewed from the perspective of the government, it was a political movement controlled and manipulated by the hierarchy of the Roman Catholic Church. This movement was the formation of coherent groups of Roman Catholics who usually had as their stated purpose some religious objective such as a national eucharistic conference. ${ }^{1}$ There is no need to discuss these societies in detail here except for three salient points. The first must be viewed in light of Article 130, sections 13 and 14:

Periodical publications of a religious character, whether through their basic purpose or title or simply through their innate tendencies, may not comment on national political affairs nor give information concerning the actions of the authorities of the country or of private individuals which relates directly to the functions of public institutions.

The formation of all types of political groups the names of which contain any word or any indication whatsoever that they have an association with any religious confession remains strictly forbidden. Meeting of a political character will not be held in church buildings.

In essence these laws forbid any political activity by

${ }^{1}$ Alicia Olivera Sedano in her excellent Aspectos del Conflicto ReligReligioso de 1926 a 1929 discusses the formation and evolution of these groups beginning with the publication of the encyclical Rerum Novarum of Pope Leo XIII in 1877. 
religious groups. From the point of view of the men who wrote the Constitution of 1917 there were good reasons for writing these sections.

This was a time when there was no well organized political party in Mexico. There had been Conservative and Liberal political groups since the middle of the nineteenth century, but these groups were identified by their religious affiliation in the case of the former, by their lack of such affiliation in the case of the latter as much as by a coherent set of political principals and goals. Indeed, Alvaro obregón himself points out this fact to Calles. Sedano says of this:

The years between 1914 and 1918 culminated in the adoption of the new Constitution of 1917. That period is characterized by a series of upheavals and tremendous disorganization. The nation required many things [to become stable]. Among the most urgent in the economic sector was to bring about agrarian reform and to stimulate commerce which was nearly dormant due to the constant battles between the diverse factions of the war. The other clear cut necessity was to create well defined political parties, permanent and organized, which until this time had been merely groups formed around strong political bosses and not on principals. ${ }^{2}$

Her second point is illustrated by the fact that until, and even after, Carranza called his forces the Constitutionalist Army, the various groups fighting in the civil war were known by the names of their various leaders: Zapatists, Villistas, Carranzists, et al. On the other hand, for almost four hundred years the Roman Catholic Church, first during the Real Patronato, then during the Republic, had been the largest, 
best organized, and most stable institution in all of Mexico. Furthermore, even though she had lost most of Her financial power during La Reforma, She had retained Her spiritual and psychological influence, a cadre of leaders in the priests, several means of mass communication, places where people could congregate, and national leaders in the Mexican episcopate. In short, in a country, the population of which was well over ninety percent Roman Catholic, the Church had all the resources necessary for starting a large and vigorous political movement, if not a party per se, at little or no financial cost. It is little wonder that the men who occupied the seats of power, apart from their personal feelings about religion and the Church, feared these religious groups as a potential political threat. This fear increased after the affair of El Cristo Rey.

This affair had begun in 1914. In that year several Catholic groups including the Partido Cathólico Nacional wished to carry out a religious event: "That the national consecration to the sacred Heart of Jesus be made by the Mexican nation." ${ }^{3}$ Acting through the National Episcopate, these groups sought and received permission from Pope Pius $\mathrm{X}$ to carry out the celebration. But for two occurrences this event probably would have merited little notice in a country noted for the number of outdoor religious festivals celebrated

${ }^{3}$ ibid., p. 49. 
each year.

The first was:

El Centro de Estudiantes Católicos, in a manner designed to draw attention to the event, organized a rally which gave emphasis to the festival. Furthermore, on its own initiative it also issued the proclamation of the authority of the "temporal royalty of Christ" in various towns of the Republic where there were already organized groups and where these groups had also been observing the national homage to Jesus Christ the King on January 11 , $1914 .{ }^{4}$

The second was:

At that time there were some notable facts which strengthened the belief on the part of the Catholic group that it would be possible to effect a greater understanding between the Church and the State. The first was that the President of the Republic, Victoriano Huerta, turning a blind eye, granted the necessary permission to hold the rally in accordance with the will of the people. Second, at the same time these things were happening two generals with impeccable military records symbolizing public power and wearing official uniforms for the grand event, laid at the feet of the Sacred Heart of Jesus a crown and a scepter. ${ }^{5}$

Even if President Huerta had not been somewhat less than popular with the Revolutionaries of 1917, the symbolism of this later act of vassalage could not possibly have escaped their notice. Here indeed was a secular authority paying homage to divine power. Integral to this ceremony, of course, was the Roman Catholic tradition which had always held that the Pope is the Vicar of Christ on Earth. It was he who spoke for Christ the King. If Christ ruled literally in the temporal

\footnotetext{
${ }^{4}$ ibid.

sibid.
} 
world, then He did so by speaking through his Vicar. And the government of Mexico regarded this Vicar as a foreign prince. There is another historical incident which, though not directly related to the matter of Christ the King, should be mentioned here. In 1923 there were a few men still living who themselves remembered the French invasion of Mexico and the subsequent reign of Maxmiliano. There were who had heard from their fathers of the French invasion. Maxmiliano was not only a devout Catholic. He had also restored to the Church some lands taken by the Laws of Reform. In addition he had altered the official bandera of Mexico so that above the familiar cactus, eagle, and serpent there was a streamer emblazoned with "religion, independence, union." The Pope had blessed his endeavors.

Sedano continues:

It cannot have escaped the notice of the reader that Catholics came to the conclusion that, as long as they were not organized into one political group and installed their own members inside the political and governmental machinery, they would never be able to achieve what they had been proposing.... The course of action which had taken the Catholic movement in general and all the organizations of the same creed which had been formed up to this time consisted principally in hindering the "threatening advance of the Revolution" which was preventing the "restoration of Christian order and the temporal authority of Christ" which they were proposing. They were able to affirm from that moment that such a movement, despite having agreed with some points of the program drawn up by the Movement of 1910, was from the time of Huerta essentially counterrevolutionary. Thus, they gave opportunity to those persons who were advancing the ideas of the Revolution to arm themselves for resisting this 
attitude. ${ }^{6}$

Thus some five or six years before the Constitution of 1917 was promulgated, the lines of battle between Church and state were being drawn.

The civil war which was just beginning in earnest in 1914 brought a complete halt or greatly hindered normal activity in almost every area of Mexican life including plans by the national episcopate of the Catholic Church to build a church in the capital for "the national consecration of the Mexican nation to the sacred Heart of Jesus." " In 1920, however, as part of the celebration of the twenty-fifth anniversary of the coronation of the Virgin of Guadalupe, they decided instead to build a statue to Christ the king on a hill thought to be the geographical center of Mexico. Dedications of new shrines in Mexico were common, and at another time this event would have occurred with no particular notice. Three elements of this celebration, however, caused the government to intervene.

The first was that the blessing of the foundation took place under a tent. That is, outside the walls of a church building. This was a clear violation of Article 24, section 2: "Every religious act of public worship must be celebrated precisely within church buildings and they shall always be under the vigilance of the authorities."

The second was that Ernesto Fillippi, titular archbishop

${ }^{6}$ ibid., p. 50 .

7 ibid., p. 80 . 
of Sardis and the apostolic delegate from Rome, assisted in the dedication. Both the outdoor celebration of a religious rite and the participation of a priest not born in Mexico were in direct violation of the Constitution of 1917.

This celebration [which took place on January 11, 1923,] was considered by the government presided over by General Alvaro Obregón as an act which formed part of a greater campaign on the part of the Church which was trying to make an impression on the people for her own part by means of this grandiose and solemn religious spectacle which was an act of defiance to the government and to the Constitution itself. ${ }^{8}$

The third was that the Catholic groups had grown in size since 1914. They had also, apparently, grown in influence. Large numbers of the faithful from all parts of Mexico made pilgrimages to the Cerro de Cubilete in the state of Guanajuato in central Mexico where the statue was to be erected. In addition, priests and bishops from various dioceses throughout Mexico as well as representatives of various Catholic societies attended the dedication. This was an impressive national event. There was probably no political group in Mexico at that time which could match such a display of potential political power.

Whether the outdoor celebration of a religious service was intended as a direct affront to the constitution or the government, it is impossible to say. Yet it has been noted that the bishops could read. They also employed lawyers. It has been further noted that they were thoroughly familiar with 
the relevant articles of the constitution. It was also noted earlier that outdoor celebrations of religious events had long been a part of Mexican Catholicism. The entire celebration had been, after all, only a pilgrimage and an al fresco blessing of some rocks. Could the government have ignored the whole matter? Monsignior Fillippi thought so:

It was an outdoor ceremony in no sense of the word. I merely blessed the cornerstone, and the entire ceremony took place in less than twenty minutes. I have presided at similar functions numerous times in Mexico, and I certainly had no idea in this instance of setting myself against any federal law. ${ }^{9}$

Quirk thinks otherwise. "The building of yet another shrine was in itself unimportant. But the action of the catholics in consecrating the Republic to Christ the King was a threat that the government felt it could not ignore."10 one is inclined to agree with Quirk.

One need not doubt that Mnsgr. Fillipi had indeed officiated at many religious rites in Mexico similar to the one at Cubilete. The rest of the statement is ingenuous especially when one considers other events which preceded the celebration. One was the sheer size of the celebration and the geographical diversity which it represented. The other was a pastoral letter dated January 11, 1923 and sent by the Archbishop of Mexico, Mora y del Río who was also President of

${ }^{9}$ Quirk, Revolution, p. 134 .

${ }^{10}$ ibid., p. 131 . 
the National Episcopate.

Jesus Christ is our King, not only in the figurative sense..., but in the Real sense that He has true power to rule men and societies.... His kingdom is not of this world, but it is in this world, and it is manifested in a human society, visibly perfect, universal, and eternal, which is the Catholic Church, which possesses right none can renounce without betraying Jesus Christ and without destroying himself. ${ }^{11}$

One could argue that Archbishop Mora y del Río was himself using figurative and theological language. One cannot look at the statue erected atop Cubilete and believe that.

A statue to EI Cristo Rey, who was regarded by many Mexicans as both a celestial and terrestrial leader, in the geographic center of the country could not be tolerated by governments in Mexico. Certainly not by one as strongly anticlerical as the one headed by Alvaro Obregón.

Whatever Obregón's personal feelings, the situation was much the same as it had been at the celebration of 1914. Not only was the temporal sovereignty of Christ proclaimed; not only was there a massive demonstration of the potential political power of the Church in Mexico; but the entire celebration was led by the personal representative of the Vicar of Christ on earth, that foreign prince. One can see why Obregón took this as an affront and a challenge to the authority of the state. Apart from the symbolism of the statue, the outdoor rite held for its dedication, and that the Apostolic Delegate presided at the dedication, there was 
the fact that he had not been born in Mexico; he was not even a priest in a Mexican church. He had participated in the dedication in open violation of Article 130, Section 8 , of the Constitución Polítical de los Estados Unidos Mexicanos:. "In order to exercise the ministry of any religion whatsoever in the United Mexican States, it is necessary to be a Mexican by birth." The hierarchy of the Church could read. They were aware of this law. Obregón could not ignore this violation. He did not.

On January 13, 1923 acting under the authority granted to the President of Mexico by Article 33 of the Constitution, Obregón expelled the Apostolic Delegate from Mexico. It is curious that he did not cite as grounds for the expulsion the fact that Fillippi was a foreign priest who had taken part in the celebration and that the celebration had been held outside of the a designated church building. He did not have to. Article 33 grants the President of the Republic the authority to order any foreigner he chooses to leave Mexico within twenty-four hours and he need give no reason. Nor does that person have any legal recourse to appeal the expulsion. By this act obregón was telling the hierarchy that their activities, which had precipitated the expulsion, must cease. The Church could not violate the Constitution with impunity. As if to emphasize this, "The Minister of Government ordered the governor of Guanajuato to halt work on construction [of 
the statue] which had been begun at Cubilete."12 He also told newspaper reporters in Mexico City:

Mexico in the future intends to take steps to prohibit high foreign dignitaries from practicing their beliefs in Mexico. This privilege belongs to the clergy of Mexico, as is stipulated by the laws. President Obregón is of the opinion that this interference on the on the part of foreign prelates is degrading to Mexican clergymen, especially as there are sufficient prelates of high standing who can fulfill all obligations to the Church. ${ }^{13}$

Plutarco Elías Calles was Secretaría de Gobernnación in obregón's cabinet. Some of the implications in these quotations are harbingers of what will happen in Calles regime: The Federal Government can order the state governments to carry out specific decrees. The word privilege, in common parlance, can denote something granted by a superior power to a weaker one. The federal government will, as the Constitution allows, determine how many Roman Catholic priests are needed in Mexico. And there is the direct statement that the Federal Government will take steps to prohibit foreign clergymen altogether. The articles of the constitution of 1917 which limit the activities and authority of the Church will be enforced. There is another article which the government of

${ }^{12}$ Sedano, Aspectos, p. 81.

General obregón at the head of his well organized army established his headquarters in Tula, Hidalgo, on March 11, [1915]. The general himself, who was always known for his animosity toward the Catholic clergy and his radical ideas in matters of religion, when he was occupying the city of Mexico, ordered that eighty priests be imprisoned... for refusing to make a loan which he forced upon the metropolitan clergy.

${ }^{13}$ Quirk, Revolution, p. 133. 
Alvaro Obregón began to enforce: Article 3.

In the debates concerning Article 3 there was a great deal said about education and what its purposes and goals should be in Mexico. Certainly one of these was to turn students' minds away from matters of the "next world" and to center them on questions dealing with this one. There was, for example, a lengthy discussion concerning whether in the term "secular education" the word "rational" should be substituted for "secular". There was also the fear that the "damned ideas" of the teachers who had been in church schools would be insinuated into secular schools. There was no doubt that the principal aim of Article 3 was "to woo [citizens] from their allegiance to the Catholic Church."14 Quirk goes on to say that the clearest manifestation of this "wooing" was in the field of art, particularly in the works of the three great muralists.

Nowhere was the religious fervor of the revolution more apparent than in the secularist propagandistic painting of José Clemente Orozco, Diego Rivera, and David siqueiros... Under the Revolution this genius burst forth again, but now to glorify and explain the new gospel of the secular revival of the Church--the nationalistic government. [underlining mine ${ }^{15}$

If the Obregón government hoped to persuade most the people of Mexico to change their allegiance from the Church to the State, the field of education was no doubt a better area

${ }^{14}$ ibid., p. 116.

${ }^{15}$ ibid. 
in which to sow than in the field of art. As wonderful as the muralists' work may be, by their very nature they are confined to limited spaces. The number of people who could view them, therefore, is also limited. So too is their message. Better to send teachers into the fields with the campesinos. Obregón's chief apostle for this mission was José Vasconcelos.

Vasconcelos saw himself as the apostle of the new secular religions, and all his projects, all his public utterances were imbued with missionary spirit. His role as Secretary of Public Education, he said, was to "preach the gospel of the mestizo by trying to impress on the minds of the new race a consciousness of their mission as builder of entirely new concepts of life." And Moisés Sáenz, who later served President Plutarco Elías Calles in the Ministry of Education, wrote that his [Calles'] government was seeking "to bring into the fold of the family the two million Indians, to make them think and feel in Spanish, to incorporate them into that type of civilization which constitutes the Mexican nationality" "In Mexico," he said, "we are consciously striving to bring about national unity by means of the school."16

All of this language is more than vaguely reminiscent of that used by Calles. Vasconcelos defined the vocation of the schools as "saving the children, educating the youth, and redeeming the Indians." [He was seeking] "teachers who would imitate the actions of the Catholic missionaries of the colonies, sent among the Indians, who did not,...know the Spanish language."17 "The rural teacher was to be a priest without a cassock, carrying the banner of Revolution, instead

${ }^{16}$ ibid., p. 117.

${ }^{17}$ ibid. 
of the cross of Christ."18 And if the words of Vasconcelos echoed those of Calles, it is because the sentiments and the ideas were identical.

We must now enter into and take possession of the minds of the children, the minds of the young...because they belong to and should belong to the Revolution...to the community, to the collective body. ${ }^{19}$

Here, indeed, are the ideas of the Revolution expressed, as was Calles' wont, in the ancient metaphor of the Church. ${ }^{20}$ One of the aims of the Revolution, and in consequence the Constitution of 1917, was to establish a school system which would be a countervalent to the schools of the Roman Catholic Church. This was, in the eyes of the Revolutionaries, vital to the success of their mission.

For four centuries there had been two elements which bound the people of Mexico into an entity resembling a nation: the Spanish language and the Roman Catholic Church. Since there were some two-hundred separate and disparate languages spoken in Mexico, and since all legal and official business was carried on in Spanish, the need to continue and increase the use of that common language is obvious. The need to supplant an institution, the first loyalty of which is to a "foreign prince," was equally obvious, at least to the

${ }^{18}$ ibid.

${ }^{19}$ Daniels, FDR.

${ }^{20} \mathrm{St}$. Paul in several passages in the New Testament refers to the Christian Church as "the body of Christ". 
progenitors of the Constitution. And since the part of the mission of the Church from Her earliest days in Mexico had been to educate youngsters to be loyal to Her, a system of schools which would teach national loyalty was unquestionably necessary. Why then did the attempt to supplant the Catholic schools wait until the regime of Calles? Why did not Carranza or Obregón or both try to it? There is some indication that Carranza, at least, did exactly that.

Support for a National Church was an idea supported not only by the people who wrote the constitution and their predecessors. In 1917, oxymoronically, support came from the top.

From the triumph of the Constitutionalist revolution, Carranza together with his Minister of Gobernación, Manuel Aquire Berlanga, thought about the advantage of bringing about a schism. For that purpose they hired a false priest who was said to be a "Secret Envoy of the Holy see" named Monsignor Riendo. At that time the name of Joaquín Pérez had already been mentioned. The attempt failed. But the idea spread among the revolutionary leaders becoming fixed from that time as the bases on which priests would be able to exercise their ministries in total freedom in accord with the new norms.

1) They would separate themselves from obedience to the Roman Pontiff and from the immediate subjugation of his prelates for the purpose of forming a National Church. 2) They must suppress auricular confession and subject themselves to civil authority in the place of the Church. These were the proposals of the revolutionaries in order to bring to an end, if possible, the catholic Church in Mexico. ${ }^{21}$

Support for a National Church was not confined to the men 
who wrote the new constitution. Meyer reports that in the northern frontier states where there had never been a strong Catholic Church and where Protestants from the United States had some influence, there was popular support for such a denomination.

I should be very much in favor of the Catholic sect if it were national, that is to say, if you appointed your own Pope, a Mexican, and got rid of that immoral institution, confession, and of the celibacy of the clergy. I'm from the frontier, and in my village the Catholic Church is hardly

Thus spoke General J.B. Vargas to the Cristero leader Pedro Quintanar.

Carranza was simply too busy trying to form an entirely new nation to spend very much time on relations between the State and the Church. The National Episcopate had been opposed to those articles of the Constitution of 1917 which they found offensive, dangerous to their position, or both. Shortly after the ratification of that document they published a letter in which they excoriated the offending articles. He did not need to antagonize them at this time.

The fact that Carranza had promulgated the constitution did not mean that it would be enforced. In Mexico, for each article of the constitution, a ley reglamentaria (implementing law), to be passed by the Congress, was necessary to fix penalties for offenses against that article. Carranza had not wanted the radical constitution. Yet he had signed it. There was little else he could do when obregón and other powerful generals had given the radicals their personal support. But if Carranza had to sign it, he was not obliged to 
enforce it....There were no leyes reglamentarias, hence no crimes and no penalties. ${ }^{23}$

In the year 1923, one year before the election of Calles as President of the Republic, there appeared on the horizon a cloud which threatened the tranquility of Mexico. The cloud was the possibility of a violent confrontation between the Church and the state. On the one hand there was the Constitution of 1917 with its laws severely limiting the activity of the Church in the affairs of the state. Affairs which only the state could, by law, define. There was in power a man who was very willing to enforce these laws. On the other hand, in addition to the traditional position which the Roman Catholic Church had held in Mexico, there was the growing number of organized religious societies which, in the view of the hierarchy of the state at least, could easily be used by the hierarchy of the Church to achieve political goals. A confrontation, it seems, could not have been avoided. And a confrontation occurred.

It was a confrontation between a group of men, the Roman Catholic Episcopate of Mexico, and a single man, El Presidente Plutarco Elías Calles. The former, believing that they had received a mandate from God, also believed that they were acting in the best interests of their flock. The latter, trusting equally in his mandate, believed that he too was acting in the best interests of the people of Mexico. The 
confrontation was between one man and the Church. We know a great deal about the Roman Catholic Church. Who was the man? 


\section{CHAPTER VII}

\section{CALLES THE MAN}

Plutarco Elías Calles was inaugurated President of Mexico on December 1, 1924. The Constitution of 1917 had been in force in Mexico for seven years. During that time only one of its articles restricting the activities of churches had been enforced: the incident of EI Cristo Rey in which Calles had played a role. Within three months of his inauguration President Calles would move even more directly to seize control of the Church.

Plutarco Elías Calles is a man about whom there exists little biographical information. No thorough biography of him exists. The survey written by Henrique Krauze quoted many times in this paper is the only true biography of Calles, but the space in it is divided about equally between text and pictures. In the Biblioteca of the Archivo General de la Nación there are only five books about him or his work. ${ }^{1}$

Calles anticlerical and anti-Church feelings ran very deep. Paradoxically, in many of his speeches and writings he praises religion as a means of teaching morality to the masses

${ }^{1}$ One is a pictorial history. Two are compilations of his writings and speeches. A fourth is an account of how newspapers in the United States reported his work as President. The fifth concerns his economic plans for Mexico. The works of Meyer, Bailey, Quirk, Sedano, et al. which deal with La Cristiada give very few biographical details because there aren't many. One suspects he wished it that way. 
despite his strong feelings against both religion per se and the Roman Catholic Church particularly. His vocabulary was frequently that of an evangelist. This may not be as incongruous as it first appears. Plutarco Elías Calles wanted to rid Mexico of the Roman Catholic Church, but he wanted to replace it with another church, albeit a secular one. He apparently found some good in the institution which he condemned.

Yet the reasons why he hated the Church are obscure. Equally obscure are his reasons for using religious language and metaphors in his political writings and speeches. Some answers about the paradoxical character of the man Calles may be found by investigating his childhood and youth. This is easier said than done since there are conflicting reports about both, beginning even before he was born. Krauze's account of his heritage is as follows:

Born in Guaymas to Plutarco Elías Lucerno and Maria de Jesus Campuzano, who were not married according to one source, on September 25, 1877, Plutarco Elías Calles grew up in an environment which was essentially that of the rugged northern Mexican frontier. Indeed, Krause says that Plutarco's uncle Rafael spent "an almost legendary life, one worthy of a John Ford western." ${ }^{2}$ In such surroundings, apparently abandoned by his alcoholic father, Plutarco spent his first three years. In 1880 his mother died and he went to live with his maternal 
aunt, Maria Josefa Campuzano, and her husband, Juan Bautista Calles, whose name Plutarco subsequently took.

There is another account, however, which contains assertions inconsistent with the first.

The Turk [Calles], as he was called in the gossip of his years of splendor and mentioned by some of his associates, came from Middle Eastern heritage, although he never spoke of this. Officially, his parents were Plutarco Elías and Jesusa Campusano, both dead by 1881, when the only son of a humble obscure marriage was only four years old. ${ }^{3}$

There is also a question, again, depending upon sources, about the date of his father's death. There is a third set of inconsistencies. Krauze says Plutarco Elías and Maria Jesusa were not married. Del Rio says that they were. The question of a marriage between the biological parents in itself is not crucial. It will come up again, however, in a slightly different context.

There is still another inconsistency which involves names. In the baptismal records of the Parochial Church of Guaymas, Sonora there is recorded:

On the twenty-first of December, 1878, $I$, the undersigned, officiating at a baptism placed the holy oil and the sacred chrism on a boy child who was born in Guaymas on January 27, 1877, and was named Francisco Plutarco, the natural son of Plutarco Elías and Jesusa Campusano.

Four years later Jesusa married with a certain Juan B. Calles. Thus [the child] took the first name of his father and the second name of his step-father.

${ }^{3}$ Salvador del Rio. Los Presidentes de México Revolucion y Posrevolucion. (México: Editoria Everest Mexicana, 1982), p. 148 . 
The God-parents were Alejandro Elías and Jesús whom I advised of their obligation and spiritual relationship. ${ }^{4}$

Everything was quite in order.

The question of the marriage of the young Calles genetic parents seems to be resolved. In a small town in Mexico in the middle of the nineteen century a couple presenting a child for baptism could not hide the fact that they were not married. In addition, it is clear they did not try to do so.

No one of these points is vital to understanding the character of the man Calles. Yet taken together, they illustrate the difficulty of discovering other facts which might help. Calles' nickname, The Turk, according to del Rio seems to have had its origen in popular gossip. Krauze treats the matter more seriously.

Some persons attribute Muslim origen to [Calles]. Others circulate the rumor that he had syrian blood. For that reason in Sonora he was called the Turk. For Mexicans, everyone from the Levant is a Turk. Whether or not the rumor is true, Calles exhibited Oriental characteristics.

The rumor amounted to slander. Calles appeared like "the shameful descendent of a Turkish camel." Why did he not respond with an emphatic and temperate declaration. Perhaps because he did not give much importance to it or would not be provoked. Or perhaps because he had no clear idea of his lineage beyond his liberal grandfather. Or, what is more probable, to deny it would reveal to the upper classes his illegitimate birth and the religious and social irregularity of his birth. ${ }^{5}$

${ }^{4}$ Lauro Lopez Beltran. La Persecucion Religiosa en México. (México: Tradición, 1987), p. 116.

${ }^{5}$ Krauze, Reformar, p. 46. 
There is another view. "Probably the cause of the impossibility in which Calles saw himself with regard to showing the register of his baptism the fact of his birth was that he believed himself to be Jewish, Armenian, or Syriolebanese. ${ }^{6}$

A third heritage is given by no less an authority than Jean Meyer and is, therefore, not to be ignored.

His [Calles] family having been established in Sonora, seems to have taken an active part in local affairs during the second part of the nineteenth century, seeing that there emerged from it judges, colonels, two governors, and the commander-inchief of Mexican troops against the French. The Elias family is found related by marriage to the Pesqueiras, the Galilondos, the Larrazolos as well as other reputable families.?

Knight agrees with this view and cites the fact that Plutarco Elias the elder was "a wealthy hacendado of known family, [who] had looked out for his bastard son and helped him through his chequered[sic] career." ${ }^{8}$

These three different and disparate account of Calles' background are both indicative and symbolic of the difficulties one has in attempting to discover anything about the man Calles. We have, in fact, very little, save his public persona. And while the circumstances of Calles' birth or even his ethnic background were probably of little moment, what was

\footnotetext{
${ }^{6}$ Beltran, Persecución, p. 115.

${ }^{7}$ Meyer, Revolution, p.120.

${ }^{8}$ Knight, Revolution, $2: 218$.
} 
very important is an allegation to be discussed below. That allegation questioned Calles very right to run for the office of President of the Republic of Mexico.

Whatever the actual circumstances of his birth may have been, He became part of the conflict between Church and state early in his life. When he began his education in the state schools of Sonora, a conflict between these schools and those run by the Roman Catholic Church began. The Church had recently begun to use more contemporary means and methods of education. These were a threat to the state schools. With these newer methods and means there began to appear both Protestant Bibles and propaganda. The young Calles was a witness to this conflict. Even as a youth he was against the Church: "As kid, when I was an acolyte, I used to rob the poor box in order to buy candy." 9

of the sort of student Calles was, we have no record. We do know that he followed a course of studies which finally led him into the teaching profession. At age twenty he was an elementary teacher in Guaymas and, according to Krauze, slightly alcoholic.

He also, again according to Krause, had some psychological problems. He revealed these in lines of a poem he entitled "Doubt" :

...in the night, the brightness of

${ }^{9}$ Krauze, Reformar, p. 12. It is interesting that in one of the few autobiographical statements by Calles sets himself against the Church. 
my soul and conscience has changed into a terrifying specter.

And my mind is left in an altered chaos. My soul is in the midst of pain. ${ }^{10}$

Such sentiments are not unusual for a young man. Krauze sees them, however, as the result of what a later generation would call an "identity crisis" caused by Calles' illegitimate birth and the fact that his father abandoned him altogether. Krause also sees his lack of a father as Calles' reason for denying the power of religion.

In either case, Calles soon lost his position as an educator. Again, the reasons for this are not clear. Perhaps he was merely unsuited for the profession. Contemporary descriptions of Calles lead one to believe that he did not have the resilient personality required to successfully teach young people:"General Calles has a physique suitable for a dictator. His character that of a wild animal trainer and one who stomps on toads."11 The chargé d' affaires of the French legation in Mexico described Calles:

He is a realist and cold, of a espiritu claro and firm convictions. Sometimes his scowl adopts an almost sinister air. One of his contemporaries left this description: "He is a heavily-built man with broad shoulders and a somber attitude. One is well able to say of him: Here is a block of human granite. His countenance is harsh, lined with aggressive features. It is a face of bronze which rarely relaxes. His eyes are small, sunken and without expression. His hair is black now tinged with grey and his trim moustache seems out of place

\footnotetext{
${ }^{10}$ ibid., p. 14

${ }^{11}$ ibid., p. 39.
} 
on a face so severe." 12

His manner of speaking seems also to have reflected a rather dour personality. One popular saying about him: "En el hablar es parco/Plutarco."13 (In his speaking he is parsimonious Plutarco.) Of his character Calles himself says: "Pero no está de acuerdo con me carácter decir algo que yo no siento...."14 (It is not in my character to say something which I do not feel.) There are two incidents which show that Calles was indeed a man of conviction.

He was an early Madero partisan and 1912 was given the job of chief of police in Agua Prieta.He seldom tolerated dissent. Once, when a laborer shouted "Down with Madero!" in public, Calles ordered him hanged by barbed wire from a railroad bridge. ${ }^{15}$

The other episode is related below.

After his failure at teaching, Plutarco embarked on a series of jobs, all which involved small businesses and at all of which he failed. One of these enterprises was a mill which he managed with the man who was to become his life long friend, Santiago Smithers. In september of 1911 Calles was appointed comisario of Agua Prieta by the governor of Sonora. His chief responsibilities were to administer justice and the custom houses. With the outbreak of the civil war he joined the Constitutionalist army of Carranza. As a successful field

${ }^{12}$ ibid.

${ }^{13}$ ibid., p. 42 .

${ }^{14}$ Calles, Correspondencia, p. 186.

${ }^{15}$ Bailley, Viva Cristo, p. 48 
commander under Obregón, he acquired the rank of General and continued to use that title even when he was President.

This political appointment and his military success marked the beginning of Calles' political career. It was a career for which Calles had great affinity. Apparently, he also embarked upon that career with an evident determination to improve and enhance the lives of all the citizens of Sonora particularly in two areas: alcohol and education. The following proclamation, issued August 15, 1915, four days after he assumed office as governor of Sonora, speaks for itself:

Taking into account:

that one of the causes of the decadence of our people has been the use of intoxicating beverages, which has further produced the debilitated physical condition and moral corruption of the individual, and that it is also one of the principal contributors to our poor economy;

that it is well known that there is a direct correlation between the use of alcoholic beverages and criminal acts and that the constitutionalist government has the obligation to improve the morality of the citizens who are under its protection and to strive for their improvement, it cannot fail to concern itself with immediate legislation concerning so important a matter. (underlining mine) ${ }^{16}$

The decree which follows absolutely forbids the importation, manufacture, or sale of alcoholic beverages. An alcoholic beverage was defined as any beverage which contained any

${ }^{16}$ Plutarco E. Calles, Plutarco Elías Calles Pensamiento Politico y Social, Antologia (1913-1936. (México: Fondo de Cultura Económico, 1988), p. 40. 
alcohol whatsoever. Violators were to be sentenced to five years in prison; their accomplices to three. As in the matter of the dissenter hanged with barbed wire, Calles immediately showed that he meant business with his decree. "The penalty was five years in prison, but to show that he was serious, Calles ordered the shooting of an unfortunate drunk in Cananea. "17

In the United states about this time, the time when the Eighteenth Amendment was passed, there was an apothegm: "Drink is the curse of the working class." This is an idea with which Calles agreed completely. Many times in his speeches he refers to the trouble strong spirits have caused the people of Mexico. One wonders why, when he was President of the Republic, he did not attempt to pass some sort of law prohibiting alcohol as he had when he was governor of Sonora. Perhaps he had seen the results of Prohibition in the United States during his visit in 1924. There remains a question about the cause or causes of his strong feeling against the use of liquor? It is well known that very often among religious persons there is a strong aversion to alcohol. That is not to argue that persons who harbor strong feelings against the Church must also favor drink. Calles feelings about drink were clearly as strong as his feelings against the Church. He did not discriminate. He damned them both. We have reasons certain for neither damnation. 
It would be both glib and easy to say that these feelings had their genesis in either the fact that his father was an alcoholic; or that Calles himself had some problems with booze; or a combination of them. Shooting a man for public intoxication, however, seems a rather extreme way of making one's point. Yet there is precedent for it in the history of Mexico. Among the Aztecs the penalty for public intoxication was death. The Freudians might say that he was symbolically shooting his father. That could, perhaps, explain his hatred for drink. It does not explain his attack on the Church which has for most of Her history been referred to as Holy Mother. Unless, perhaps, one wants to argue that he was punishing his mother, again symbolically, because she had abandoned him just as his father had. He through drink and desertion. She through death. As noted in the shooting of the town drunk, Calles did not hesitate to use lethal force in concrete situations. Why would he hesitate in a symbolic one?

From this evidence one infers strongly that Calles was both direct and decisive in dealing with his enemies. He seems to have acted from an almost military idea that if one has the power and one is faced with a dangerous enemy, use that power to annihilate the enemy. If a man shouts anti-Madero slogans and you are the Maderista in power, hang him with barbed wire. If you hate priests and have the power to banish priests from your state, by all means do so. If one views alcoholic beverages as the enemy of your state, ban it. If the town 
drunk ignores this ban, kill him. If one regards the Church as one of the great enemies of your nation and one is the President, crush it.

There is, of course, another very obvious reason why Calles hated the Church; one which contemporary readers might overlook. Plutarco's mother and father were not, according to one view, married. In fact, according to Krauze, Plutarco the elder was never married to anyone, though he sired several children by women other than Plutarco the younger's mother. ${ }^{18}$ Krauze believes that Calles was denying his illegitimate status by denying the power of the church. The matter of his birth was also brought up by his opposition during his presidential campaign of 1924.

In July 3, 1923, issue of "Omega," a Mexico City daily, the charge is leveled that, "...Señor Calles is the son of a foreign father and a Mexican mother." Another source is more explicit:

His name is certainly not Mexican. Elías is Syrian, or Turkish [or Jewish]. For this reason the Mexican people call him the Turk. The Constitution requires that the President of the Republic be Mexican by birth and the son of Mexican parents. Are both requirements fulfilled in the present dictator. Nobody knows with certainty. ${ }^{19}$

If this were true, Calles could not be a legal candidate for President, since the Mexican constitution then in force stipulated that to be President a man must be the child of two

18ibid., p. 13.

19Beltran, Persecución, p 116. 
Mexican citizens. It would also answer the question of why Calles did not clear up the question of his ethnic origins raised by the epithet The Turk. Whether the charge is true cannot be determined here. Yet the charge had been made. Apparently, Calles dealt with it adequately. We do not have a record of how. There is one other salient point. Plutarco Elías Calles was not baptized until one year, one source says almost two, after his birth. ${ }^{20}$ Krauze says it was because his father was absent. There are two other possibilities, however.

The first is a thoroughly mundane one: It may be, because Plutarco the elder was absent, María de Jesus did not have the fee to pay the local priest for the sacrament. Thus baptism was delayed. The other possibility is that since there was no male present to acknowledge the infant Plutarco as his natural, if not legitimate, offspring, no baptism could be performed. It is not surprising that Plutarco showed little or no interest in his son's baptism: He was an atheist. ${ }^{21}$ This fact may also have delayed the baptism. The incongruity of an atheist swearing that he will raise his son in the Roman Catholic Church is apparent. In any case, it was the Roman Catholic Church who was deciding whether Plutarco would ever behold the Beatific Vision. Catholic doctrine held that unbaptized infants went to Limbo rather than Heaven. And while 20 Krauze, Reformar, p. 9. 
this surely meant nothing to the infant Calles, it was the sort of thing which would rankle the adult.

And it is the adult with whom this thesis must deal. One of his most prominent and consistent characteristics was Calles' devotion to law. Not law as an abstract concept, but laws established by men. Throughout his career he was absolutely adamant that once a law was promulgated, it must be obeyed without question. Indeed, as we shall see, his strong and earnest attempts to enforce established law were the proximate cause for the rebellion which came to be called La Cristiada.

"It has been said with good reason that the governance in Sonora was a political laboratory which foreshadowed [Calles] attitude as President." ${ }^{22}$ Shooting the town drunk, for example, while it proves little by itself, was a harbinger of what one could expect from Calles when he became President of the Republic. So was the fact that as governor of that state he banished all Roman Catholic priests. He also issued a program which called for the building of many new schools. To suppress the church and to encourage education were two elements of Calles' program for sonora. Later they were to become elements of his program for Mexico. Indeed, it will be shown that these elements were yoked. They were joined because together they were "... to bring Mexico into full 
incorporation of a civilized life."23 The yoke was to be the law.

The conviction that the law in all its particulars should be stringently enforced is clear. That he had a personal animus against the Roman Catholic Church and that he wished her ill is equally clear. For example, Henry Sheffield, the American ambassador to Mexico, reported to secretary of state Frank Kellog:

The President[Calles] became so violent over the question of religion that he lost control of himself. When the matter was brought up in his presence, his face became inflamed and he struck a table to show his hatred and profound hostility toward the practice of religion. ${ }^{24}$

And according to Ernest Lagarde, the French chargé de affaires in Mexico City, Calles viewed..." the issue of religion with an apocalyptic and mystical spirit... As a battle between the religious ideal and the secular, between reaction and progress." (underlining mine) ${ }^{25}$

If he was personally opposed to religion generally, he was even more opposed to the Roman Catholic Church--or at least Her clergy and hierarchy--specifically. Upon becoming governor of Sonora he immediately expelled all Roman Catholic priests from the state. It appears, however, that Calles intended more than merely ridding sonora of Roman Catholic

23Victor Díaz Arciniega. "Calles: El Voluntarioso."Historia Mexicana, Marzo 30, 1985, p. 461.

24 Krauze, Reformar, p. 70 .

25 ibid., p. 71 . 
priests. He wanted to supplant them with men whom he chose.

Calles,... after expelling the Catholic priests from [Sonora], wanted to replace them with priests willing to form a new Church; the semi-official periodical Orientación reported the arrival in November 1917 of Fr Ernesto Llano, who had come to take over the leadership of this Mexican National Church. (underlining mine) ${ }^{26}$

This was early in his political career. Toward the end of it his views had not changed.

The object of the Catholic Church [in Mexico], he added, was to keep the masses in ignorance and to dominate the country through an alliance with capitalism, which it had done for the better part of four centuries.

Concerning the visit of an Apostolic Delegate to Washington:

This, [Calles] declared, was part of a great plot organized in Mexico by Roman Catholic priests (than whom, he emphatically stated, there were no worse subversive agents in the world), whose program was similar to that which they had attempted to carry out in 1926 - sedition, armed rebellion, even assassination.... He repeated: "The priests assassinated General Obregôn". [sic] ${ }^{26}$

The animus is clear. Yet there is an anomaly.

That Calles believed that religion, in full ecclesiastic vestments, could be a strong moral and ameliorating force in the lives of other people (thereby making them more amenable, responsive, submissive to the wishes of government, perhaps) is beyond question. He makes this point in many of his speeches and writings. Two examples:

My enemies say that I am an enemy of religion and

26Meyer, La Cristiada, p. 35.

${ }^{26}$ Meyer, La Cristiada, p.35. 
of the churches; that I do not respect religious beliefs. I am so broad minded in spiritual matters that in my own mind I understand and approve all religious beliefs because I consider them good for the moral program which they encompass. I am the enemy of the priestly caste who see privilege in their position; not an evangelical

mission. I am an enemy of the political priest, the scheming priest, of the priest who is an exploiter, of the priest who tries to hold our people submerged in ignorance, of the priest who allies himself with the hacendado in order to exploit the campesinos or with the industrialist in order to exploit the worker. I declare that I respect all religions and all faiths so long as their ministers do not show contempt for our laws by involving themselves in our political struggle nor serve as instruments of the powerful in order to exploit the poor. (emphasis mine) ${ }^{27}$

If one compares this quotation from Calles' political campaign in 1924 with the quotation above given to Ambassador Daniels, one can see several interesting things. First, Calles strong anti-clerical feelings were consistent and of long standing. Second, in both quotations he shows that he believes the clergy of the Roman Catholic Church is closely allied with the rich and powerful. Third, Calles presents himself as leader of those who would break the hold of the plutocraticclerical oligarchy who controlled Mexico for their personal advantage and to the detriment of "proletariat." And though this is the word which calles used in neither of the quotations just cited, it is one which he used frequently, one which raises two questions relevant to this paper. What were Calles' political beliefs? How did they affect his relations with the Roman Catholic Church? 
There is a further bit of evidence which indicates Calles personal convictions about religion and its alleged symbiotic relationship with plutocratic capitalism. Before his inauguration in December of 1924 Calles toured first Europe and then the United States. According to Krauze

It was surely in the United States that he acquired a work which he devoured: The Profits of Religion by the North American author Upton Sinclair. The first lines of the book were very significant: "This book is a study of Supernaturalism from a new point of view--as a source of Income and a shield to Privilege.... It contains the facts." 28

Sinclair, best known today for his novel The Jungle, was an ardent Socialist and a rather talented polemicist. When one reads The Profits of Religion, one finds that the book is nothing more than a wordy expansion of Lenin's dictum about religion, opium, and the masses. Sinclair is, however, very catholic in his condemnation of organized religion. There seems to be no faith nor religion known to the world in 1917, the book's date of publication, which escapes his indictment: They are all nothing more than money raising enterprises designed to increase the wealth of the already wealthy and to ensure that the poor remain poor. There is another dimension to this book which should be noted here.

It is clear that Calles was familiar with the socialist thought of his time. His language and metaphors attest to this. Yet in neither the compilation of his political thought and writings, Pensamiento Politico y social, nor in 
Correspondencia Personal is there a citation or a quotation from any socialist authors; not even Karl Marx. Are we to suppose that The profits of Religion is the only socialist literature Calles ever read? One finds that hard to believe. While it is frustrating to say so, one must admit that his lack of citation or reference to socialist writers and theoreticians is simply one of the aspects of his character which make Plutarco Elías Calles an enigmatic figure. The actual sources of his knowledge of socialism remain equally unknown .

Calles has been characterized and labeled by both friends and enemies in many ways. Rather than add to or concur with those characterizations and labels, let the man's words speak for themselves:

But now we have in this city [Mexico] the representatives of the workers of a great part of the countries on the American Continent. Banking, commerce, industry, and the strong forces of capital have not taken into consideration these delegates, this convention which, in my opinion, represents the soul [underlining mine] of these nations. Because it is precisely in the proletariat of the entire world where beats the national soul of all the nations. Although the strong forces of capital are not represented, the government of Mexico--eminently democratic, a government made up of men who live sustaining a formidable battle for many years against all the traditions, against all the errors of the past, against all the stagnation which is the death of humanity--this government, I tell you, carries on this battle which is the battle of the proletariat of the world. ${ }^{29}$

This was part of speech delivered before the Third Convention of 
the Pan-American Confederation of Labor, 20/1/1921.

For sometime now men oriented toward the past have been mounting a crusade (underlining mine) against me, calling me a Bolshevik, as if that word would cause me some offense. ${ }^{30}$

For the time being we must depend on private initiative, guided, aided, and channelled by the

State fostering a just distribution and opening the breach toward a socialist state. ${ }^{31}$

From an interview with El Demócrata, a Mexico City newspaper:

What is [Calles] opinion of Bolshevism?

That in Mexico it is to a man's advantage to be called a "Bolshevik." Certainly it is for me. I am called an "extremist" by my adversaries, but only because I do not want to oppose the currents of renewal which are washing away the old and wormeaten systems. They are not just who thus value my work. They have little knowledge of what is happening in the world. Social renewal is a current which today invades all the societies of the world and it is necessary to guide violent currents, to find the channel which contains them, converting them from agents of destruction to useful but harmless elements. ${ }^{32}$

I am absolutely convinced that the Revolution will triumph, following completely an ineluctable law of history. ${ }^{33}$

One view from an outsider also says a great deal. They are the first words of Alejandra Kolontai, first ambassador from the Soviet Union to Mexico, upon presenting her credentials to El Presidente Calles. "There are no two nations in the entire

30ibid., p. 55.

31 ibid., p. 308 .

32 ibid., p. 103.

33 ibid. 
world with greater affinity than modern Mexico and the new Russia." ${ }^{34}$ Here again are Calles' own words:

I believe also that sooner or later the destinies of all the peoples of the Earth will be in the hands of the workers, and then it will be that the day of happiness for mankind will arrive. ${ }^{35}$

In another context the content of this sentence would be called messianic.

Finally, a quotation from a later source. As noted above, Venustiano Carranza in his capacity as first chief of the Army had appointed Calles governor of Sonora."From that time on his was regarded as a 'man of the future' and as the man uniquely able to establish a socialist republic in Mexico."16 It is clear that if one is inclined to place political names or label upon politicians, one would hardly choose "capitalist" or "conservative" for Calles. But we must never forget that Calles was a man of paradoxes.

In his book La Rebelión de los Cristeros (1926-1929) published in Moscow in 1965, Nicolás Larin gave a decidedly different view of Calles.

Plutarco Elías calles himself, speaking at banquet organized his honor by the Chamber of Commerce of New York said: "I have been portrayed by the press as a destructive man and as a man without the capacity to promote the well being of his nation. Let me assure you, gentlemen, that this is not true. My program is eminently constructive and eminently logical... You can be sure that the ideals

34 Krauze, Reformar, p. 62 .

35Calles, Pensamiento, p. 148.

${ }^{36}$ Sedano, Aspectos, p. 84 . 
which we pursue and the improvements which we are trying to effect will not be an obstacle to the development of industry or commerce. ${ }^{37}$

Larin continues by quoting two laudatory statements made by Julio Jahket [sic] and Alejandro Jenin, presidents respectively of the German and French Chambers of Commerce.

These appraisals relative to Plutarco Elías Calles contain the fundamental quality which characterizes him: the desire to create a powerful Mexican national bourgeoisie. He fell into line by shaping and strengthening that class. There were also changes in the speeches of Plutarco Elías Calles who travelled the road from "quasi socialist" to being a declared enemy of the Soviet Union and an anticommunist. The Communist Party of Mexico defined plutarco Elías Calles correctly calling him a "leader of a party of the rich during the revolution." ${ }^{38}$

From his own words one can infer at least one correct conclusion about Calles: He wanted a completely secular government in Mexico, not one which showed even the slightest favor to the Church.

There is, however, another facet of this man to which attention must be drawn. It is that he used religious words and metaphors in contexts which were manifestly political. There are many, many examples of this; a few will illustrate. In the Pensa he speaks frequently of "the confession of my revolutionary faith;" milagros, miracles p. 73; sacrificando, sacrificing, passim; profesión de la fe passim; de las rendención de proletería, passim, see especially pp.

37Larin, La Rebelión, p. 85.

38 ibid., p. 86 . 
99-101. On p. 74 he refers to his fellow revolutionaries as "mis correligionarios." And after the fighting between the forces of los Cristeros and those of the government had begun, Calles spoke of the war in terms which one might reserve for Aramageddon:

I believe--I declare for these days --that we are in a time when the two camps will be divided forever; the hour is near when the final battle for freedom will occur; we shall soon know if the Revolution has defeated the reactionaries or if the Revolution has been ephemeral. ${ }^{39}$

Another, longer quotation from his campaign for the presidency can be interpreted either communistic or Christian in its point of view. Calles use of religious metaphor, however, is undeniable.

You who can hear me now can be assured as can the entire nation that I shall fight in every form and in every field for the final triumph of Revolutionary principles. I shall enter the battle knowing that the Revolution has given me the responsibility of raising its sacred banner and that I shall go forward with the militancy I have always held, hold now, and will hold: Unquestioning faith in the triumph of our cause. But if I should encounter some chance defeat because of obstacles which reaction has placed in my path and which might be more than my strength, there will come another day in which our cause, the redemption of the, proletariat will be unfailing and triumphant. (underlining mine) ${ }^{40}$

Whether these words stem from the Bible or the Communist

Manifesto or both cannot be determined. The point is that Calles used the words of the Church to achieve his own ends.

39Krauze, Reformar, p. 71.

40 calles, Pensamiento, p. 80. 
"Even the Devil can quote scripture...."

There are three likely reasons why calles used this "religious language" and imagery frequently. The first is that Mexicans are a people whose religion is practical for and practiced by many of them. They were used to hearing such words as sacrifice and redemption. For them these words carried the same meaning when applied to an economic or political situation as they did when a priest was reminding the people of diezmo, the ten per cent tithe asked by the Church and required in the early constitutions of Mexico. To transfer the meaning from a religious setting to a political one was probably not difficult.

The second reason has to do with the nature of revolutionary movements. This writer is not the first person to notice that staunch revolutionaries call for exactly the same sort of fervor and discipline which is called for by devoted religious leaders. Compare, for example, the exhortations of St. Ignatius Loyola in his Spiritual Exercises with those of Lenin in What Is To Be Done? Each tells his readers what they must do in this present, suffering world to realize surcease of suffering in a world yet to come. They must organize and act. Or, "Sell all that you have; give the money to the poor and take up your cross and follow Me."

The third reason is closely linked with the second. Calles was, as we have seen, devoted to improving the morality of the Mexican people and believed that it was the duty of 
government to do so.

It is the job of government to place its whole moral and physical efforts into bettering the unfortunate classes, into better guidance of the laboring masses, into raising the mentality of the slow, and into constantly improving the standard of living of the oppressed. ${ }^{41}$

We have also seen that he believed that religion and the churches could help him in this crusade against vicios. Again, he was using language with which Mexicans were already very familiar. Here he did not even have to change the context. A call for sobriety is a call for sobriety no matter who issues it. In his very first edict which banned alcoholic beverages Calles, as we saw, said that his government had the obligation to "make moral" the citizens of sonora. The theme of total self-control which leads to total abstinence is frequently in his speeches.

Your [moral] obligations must begin with yourselves. All men have the duty to be moral; to be good men; to banish and fight your vices. And among those vices alcoholism figures most prominently. Each individual has the obligation to get rid of the vice of alcohol. ${ }^{42}$

The words moral and morales occur repeatedly his speeches and they

are often combined with intellectual, cultural, and económico. These phrases indicate an important facet of the man Calles which must be regarded since it generated one of the crucial issues between his government and the Constitution of 1917 and

4 Arinciegna, "Calles", p.460.

42Calles, Pensamiento, p. 58. 
the Roman Catholic Church. That facet is his dedication to secular education.

On August 4, 1915, Venustiano Carranza, self-proclaimed Primero Jefe de las Revolución, named Plutarco Elías Calles governor of the State of Sonora. On the same day Calles issued his programa de gobierno which began, "This program does not concern itself with empty promises, but with the ideals which are now being perfected by the redeeming work of the Constitutionalist revolution."[underlining mine] ${ }^{43}$ The third step of his program deals with instrucción publica. There is very little in this program with which anyone interested in educating people who were, for the most part, analphabetic, could find fault. The program was not an empty promise. Calles had the authority to enforce his program; and he did. Coeducational schools for both children and adults were established. There was academic as well as vocational training. Attendance was obligatory. Classes were established for every twenty persons. An Escuela Normal was established in the capital. The building of schools and encouraging of education for his people did not end here. Calles pursued this end throughout his political career. After he became president:

In the City of Mexico the Callista regime introduced various educational innovations: Primary secondary schools were opened; a department of technical and industrial instruction was funded, and, for the first time, classes for every 
sort of instruction were broadcast by radio. There was also established in the capital the Center for Native studies, the purpose of which was that the speakers of the 200 monoglot languages all be taught in the same tongue. ${ }^{44}$

Clearly, Calles believed deeply that education was good and necessary for all the people of Mexico.

He insisted, however, that all education, at least through the elementary grades, be rigidly and strictly controlled by government. He made the reasons for this clear: One was that Article Three of the 1917 Constitution required it. Another was that he believed that education controlled by religious bodies had a purpose completely different from that which was controlled by secular authorities.

The General replied that education of a sort was widespread [prior to the Constitution of 1917], but that it left the people in ignorance, as a consequence many millions of Mexicans were now [1934]living in primitive conditions. The object of the Catholic Church, he added, was to keep the masses in ignorance and to dominate the country through an alliance with capitalism, which it had done for the better part of four centuries. ${ }^{45}$

When he assumed office on December 1, 1924, Calles was determined that, following the dictates of Article 3, all elementary education in Mexico would remain out of the control of religious authorities. He also began rigorously enforcing the other articles which were clearly aimed at limiting the spiritual, psychological, and secular influence of the Roman Catholic Church. It is by enforcing these articles and the two

44 Krauze, Reformar, p. 57.

45Daniels to FDR. 
decrees which he later promulgated that Calles hoped to break once and for all time the enormous power which the Church still had in Mexico. He hoped to do this by enforcing laws which had been written in 1917, but had never been, except on one occasion, strictly enforced. But who was the man who would enforce these articles and laws. We have been left two contemporary descriptions which, perhaps, tell us. The first is by a Frenchman.

He is tall, broad shouldered, a face which is at once both violent and reserved, with a kind of fire in his eyes. There is not a one trait nor a single gesture which suggests that there is in the man even one drop of Latin blood and certainly not Celtic. He is no Oriental with there deceitful laziness. Nor is he a nimble Indian. Nor a Semite. He is a type apart. I see him as a wild beast at rest who will soon grind down any assailant. ${ }^{46}$

The second is by an American:

For one reason or another Calles feels an intense hatred for the Catholic Church, a hatred almost as great as that of Cromwell....A North American journalist who was in Mexico had on one occasion the opportunity to discuss fully the religious question with Calles; or better said, to listen for an hour and a half to what calles had to say concerning the matter. The correspondent is a Protestant and not particularly interested in religious matters. But he left that interview in a cold sweat, and he told me (when he was able to recover the use of his voice) that Hellish tone of the words of the Dictator had shaken him. He was as the font of these words--he told me--not the hatred of one lifetime, but many generations of hatred. ${ }^{47}$

Ecce homo!

46Beltran, La persecución, p. 116. $47 i b i d$. 
CHAPTER VIII

BURDAR AND THE SEIZURE OF CORPUS CHRISTI

The black cloud covering the relations between Church and state which had begun to grow at the celebration of the sacred Heart of Jesus in 1914 and grew more menacing at the Cubilete in 1923, became a full-fledged tempest in the winter of 1924-25. For the first time people were killed.

On the night of February 22, 1925, a group of about onehundred armed men, among them Ricardo Treviño, secretarygeneral of CROM entered the Iglesia Soledad in the San Lazaro section of Mexico City. With threats of violence they drove out the priests who served in that church. Shortly thereafter, Joaquin Pérez Burdar, a sometime Roman Catholic priest, accompanied by another group of armed men, arrived and ensconced himself there as "Patriarch of the Mexican Catholic Church".

Like Calles, the man whose help Pérez sought in order to achieve his goal of a Mexican Church, very little is known of his personal life. Born in Oaxaca in 1851 he seems to have fought with Diaz against the French invaders under Maximiliano. Married at twenty-two, he became a widower a short time later. Whereupon he entered a seminary and was ordained a priest in 1881. Paradoxically, he was also a Mason. He was imprisoned for conspiring against the government, but 
was later freed by Díaz. He re-entered the army and then became a parish priest until January of 1925. It was then that he was one of the shock troops in Calles first attack against the Church.

Joaquín Pérez Burdar was a schismatic. And while he was not in the militant theological tradition of Luther, Melanchton, or Calvin, nor even a reformer in the usual sense, he did wish to begin a movement within the Roman Catholic Church in Mexico which would sunder Her ties with Rome, form a national church, and perhaps go even further. Though Pérez Burdar in no way resembled the militant Reformers of the sixteenth century in their battle for theological and liturgical changes, he was quite like them in another. In order to found his new church, he asked for and received assistance from some of leading contemporary political figures.

Shortly after the invasion, Burdar was joined by a Spanish-born priest, Manuel Monge. On the following Monday, when Father Monge, despite the fact that he was not "Mexican by birth," attempted to celebrate the eucharist, about onethousand people rioted in protest. There were injuries and one death was reported. At this point the "Patriarch" and Monge sent a wire to Calles pleading for help.

Whereas we are under the protection of the Federal Constitution and being Mexican citizens[sic] practicing as our faith the Mexican Apostolic Catholic Religion, it is respectfully requested that you be so good as to execute the guarantees granted me[sic] in the constitution to remain in 
this church. (underlining mine) ${ }^{1}$

It is not clear whether Perez is using the Papal we or speaking of both himself and Monge. According to Bailey, "The president promptly assured them that the necessary orders had been given." ${ }^{2}$ It was reported in Excelsior, the Mexico city daily, on February 24, 1925 that Gilberto Valenzuela, Calles' Secretaria de Gobernación, and therefore the minister in charge of State-Church relations, sent a message to Pérez in which he said

the government was completely neutral in the controversy and that it would not tolerate ministers of one creed using force to take over buildings belonging to the nation which had been entrusted to ministers of another creed. But then he added a comment that did much to confirm Catholic suspicions: "The members of the Mexican church [i.e. the Pérez group] must not resort to censurable methods to obtain what the authorities are prepared to grant them provided they seek it peacefully and comply with the requirements of the law. ${ }^{3}$

Oddly, this government which said that it was completely dedicated to fulfilling the requirements of the Constitution, was willing to hand over national property to a "patriarch" whose closest associate was a priest born in spain.

In a lengthier communique dated a March 3, 1925, Pérez gave some reasons for the takeover.

One of our principal motives for supporting an independent Mexican Catholic Church completely

\footnotetext{
${ }^{1} \mathrm{AGN}, \quad 103-438-\mathrm{M}-6$.

${ }^{2}$ Bailey, Viva Cristo Rey, p. 51.

${ }^{3}$ ibid.
} 
separated from the Roman Vatican is our firm resolve to divorce ourselves from the influence of the Pope who compelled the Roman Church [in Mexico] to become a faction opposing the laws of our country and her duly constituted authorities... This Patriarch has as his unswerving purpose to be in accord with our principles, especially those which, as he mentioned earlier, are characteristic of our nation. Those are the ones which we seek to impress indelibly on the acts of our Mexican Apostolic Catholic Church. We shall always support the laws of our country and the orders of our government. It having been shown in the specific case to which we are referring that our Church has fulfilled completely the order which you have dictated... Using that right which that same order recognized: That the Mexican Apostolic Catholic Church occupy the temples of our nation and dedicate them to our religion. ${ }^{4}$

Here is, without a doubt, an overt attempt to begin a new, national church. As we have seen in chapter four, it was not the first. There are some points, however, which must be noted.

One is that there is no mention in these writings, nor will there be in later ones, of theological issues or even issues of polity. It is a straight forward request for help from President Calles in founding a national church. One which has absolutely no allegiance to the pope and is totally committed to obeying the laws of Mexico. A second point is that implicit in these telegrams is the notion that the secular authority of the state does in fact have the right to decide what the religion of the nation will be. Cuius regio, eius religio. This notion was, of course, also inchoate in the 
Constitution. A third is that the secular authority will somehow be willing to support a non-Roman Catholicism as a national church rather than another denomination. It is also clear that Pérez Burdar and company believed that calles had given all the churches of the nation to them. As will be seen, however, what secular authority can give away it can also take away. And that is what Calles did.

Throughout the country, however, only five or six Roman Catholic parishes went over to Pérez, and in these parishes there was physical violence resulting in more injured and dead. The attempt to end the influence, if not the existence of the Roman Catholic Church, could not be accomplished by a frontal attack. As the schismatics should have known, she had more power than a single anti-Madero political dissident or the town drunk in Cananea.

The working-class people who collected at La Soledad to fight the schismatics and police were not opposing the revolution per se. The knew nothing of the official involvement. They, or others like them, had fought in the revolutionary armies. Many of them no doubt sympathized with the revolution's objectives. They rioted when intruders laid hands on their priest and invaded their parish church, but few of them were concerned over quarrels among bishops, politicians, and young Catholic intellectuals. They were not ready to join a Catholic antigovernment crusade. ${ }^{5}$

On March 2, 1925, Monge published a statement announcing his submission to Roman Church authority. On March 14, Calles closed La soledad and announced plans to convert it to a

${ }^{5}$ Bailey, Viva Cristo Rey, p. 53. 
library. He was, no doubt, pointing up the fact that while the movement had failed, the nation still owned and therefore controlled all property formerly belonging to the church. He later gave Pérez the Church of Corpus Christi, located in central Mexico City, which had not been used for many years. The rebel parishes fell away, and in the end Pérez himself returned to the Roman Catholic Church. The schismatic movement had failed.

Chief among the supporters of Burdar was, of course, General President Plutarco Elías Calles and the members of his government, especially Luis Morones who was head of the CROM and Secretaria de Industria. Morones was as violently anticlerical as his President. Another soldier in the anti-Church crusade, though apparently a reluctant one, was Gilberto Valenzuela Secretaria de Gobernación. That men with such power and prestige backed a movement dedicated to schism with Rome would seem to have guaranteed the success of that movement. Yet it failed, even as earlier attempts had failed.

Pérez Burdar was not the first man in the history of Mexico to attempt a break with Rome, though his act of rebellion was certainly one of the most overt. As an opening for schism it was certainly more dramatic than Martin Luther's nailing ninety-five theses to the cathedral door, and was it was also better organized. At the beginning of his movement Martin Luther was acting alone. Pérez Burdar most certainly was not. Calles or members of his government were directly or 
indirectly involved in the movement and the initial attack. And though Calles, Pérez Burdar, et al. lost the first battle, they clearly did not view the lose as the end of the war.

Yet for all the support both inside and outside of government which the Calles' government might muster for a national church, it appears that it was the threat of popular resistance by Roman Catholics, even to the point of martyring themselves, which convinced Calles that a direct attack on the clergy and the churches would fail. Or at least he was not yet prepared to pay the price demanded by such an assault. What that price was we saw in the incident at La Soledad: bloodshed and death. Catholics were prepared to continue.

Is it true that the Supreme Government attacked the church and wants to do the same to the Basilica? Here many people are already preparing to defend the churches with firearms. I already have over 3,000 men, and I believe that the women are greater in number; there are probably 7,000 altogether. We would rather die than allow the clergy to be persecuted. ${ }^{6}$

This was written by the villagers of Santa Ana Chiautempán to President Calles.

Thus we see that the Pérez's seizure of La Soledad was another act in a series of acts aimed at founding a national Mexican church. We have also noted why it failed. The importance of the failure will be discussed below. First, however, it is necessary to answer two questions: 1) Did Burdar act alone? 2) Was Calles involved? Simply put, the

${ }^{6}$ Meyer, La Cristiada, p. 36. 
answer to question two is no; to question two it is yes. The answers to these two questions are related and must be treated together, not so much for the answers per se, but because of the source for the answers. The source is Gilberto Valenzuela whom we met earlier.

Although there is no precise account of all the events of February 22, 1925 it is generally agreed by most writers on La Cristiada that the CROM and their leader, Luis Morones, physically aided Pérez-Burdar in taking control of La Soledad. Most accounts agree that the assault took place in an almost military fashion. There were two waves in the "attack." The first wave ousted the pastor and his assistants. The second brought Pérez into the church. The "assault troops" in each wave were members of the Knights of the order of Guadalupe, an organization formed within CROM to counter the Knights of Columbus. Such assistance could hardly have been rendered to Pérez without the sanction of Morones. Morones was one of Calles closest aides and confidants during the election of 1924 and Secretary of Industry in the Calles government. If Calles, then, wanted to control physically the Catholic Churches in Mexico without using the troops of the federal government or the local police, there were plenty of other "troops" in CROM. That this is actually what took place was attested to by Gilberto Valenzuela.

As if those elements which General Calles had been handing over to Morones were not sufficient for the complete realization of his ambitions for power and domination in the Republic, he was contriving with 
some of his leaders and was sanctioned by Calles in all his own areas: The creation of a religious force which would be able at the same time to expound social and religious forces. From this arose the miscarried notion called the Mexican Catholic Church....

Thus I believe that cunningly the religious problem was contrived in all its manifestations by Morones and by Calles with its only purpose, base and criminal, to develop a new force, the force called the Mexican Catholic Church in order to consolidate and guarantee the absolute dominance, the complete and definitive tyranny of Morones and Calles over the Mexican people in every aspect of their social lives. ${ }^{7}$

Though Valenzuela was running for the office of President by opposing the re-election of obregón at the time he made this statement, there are two reasons why his account is reliable, trustworthy. The first is that it is consistent with other accounts. The second, and more compelling reason, is that nowhere does he indicate that he was in any way opposed to a national church either for personal or legal reasons. He opposed the government supporting the takeover by Pérez for political reasons and for the harm it could cause. He was opposed to Morones and Calles dominating the lives of the Mexican people. That he opposed Calles by running against Obregón is another indication of his reliability as a witness. Valenzuela in fact seems almost pleased that the Pérez Burdar "coup" failed. Calles was, no doubt, less than pleased. He would have been especially displeased if he was directly supporting Pérez Burdar and if he saw the Pérez takeover as a 
first step in his goal of creating a national church. Opinions are, of course, divided on this matter.

The so-called Mexican apostolic church was not, as Catholics later charged, a plot of the Calles government to destroy the Roman Church in Mexico. Rather the movement began almost inadvertently with the defection of two priests and their attempt to seize one of the Mexico City parishes. But it is true that members of the government--probably in Morones' office gave aid to the new Church, once the schism had started. ${ }^{8}$

Bailey has a different view.

Excélsior [the Mexico City daily] was correct regarding official involvement in the soledad-Pérez affair. Several times in the days before the seizure of La Soledad, Pérez and CROM leader Morones had held extended talks. With Calles approval, Morones pledged all-out CROM support for the operation, the object being to promote creation of a "church" that would support the revolution and replace or at least offset the influence of the Catholic church in Mexico. ${ }^{9}$

The present writer agrees with Bailey for several reasons.

All of the first hand accounts of the takeover of La Soledad agree that both rank and file of the CROM and officials of that union took part in the seizure. The officials were well-known. As Quirk himself pointed out, Pérez was an aging priest without the sanction of his bishop. Quirk fails to mention, however, that the priest, Monge, whose aid Pérez enlisted, was not Mexican by birth, but Spanish. Furthermore, Quirk's rendition of the events of the seizure makes the attack seem as if it were a rather casual affair.

${ }^{8}$ Quirk, Mexican Revolution, p. 140.

${ }^{9}$ Bailey, Viva Cristo Rey, p. 52. 
Actual accounts make it clear that it was well organized. The men involved, their association with the CROM, Morones' close association with Calles, are strong indications that Calles knew of the plan to occupy and "convert" the cathedral.

Bailey relies on the accounts in Excelsior and the statement by Valenzuela cited above, while given during a political campaign against Alvaro Obregón for the presidency and therefore self-serving, fits with the accounts from other sources. It also fits well with the feelings expressed by Calles about religions and the social value of churches, three of which are cited here.

First, Calles, unlike Pontius Pilate, did not wash his hands of the matter and avoid all further involvement. He could, as President, remain aloof from the battle. What he chose to do, rather, was to close La Soledad, his right under the Constitution, and award to Pérez Burdar the church of Corpus Christi, a long unused building, but one located close to the center of Mexico City. That gesture, albeit a small one, symbolized the approval and sanction of the Republic of Mexico, as represented by her President, of the founding of a new Church in Mexico. It was to be a Church, as proclaimed by her founder, politically loyal to the government of Mexico, not to the Vatican. In short, Calles was in fact sanctioning a national church. One which he saw as supplanting the traditional denominations in Mexico. This act was not the renaissance of the Patronato Real in a modern form no matter 
how much calles wanted that and thought that it would occur. But it was a small victory, albeit a fleeting one, in the larger war which Calles was sure the state would win.

In a report from United States Ambassador Josephus Daniels dated November 2, 1934, Daniels reports that in a personal interview with calles a few days earlier, the latter defended the most recent expulsion of priests from Mexico.

The Ambassador commented on the possible adverse effect throughout the world which the expulsion from Mexico of high ecclesiastic authorities might have on public opinion, to the injury of Mexico.

The Ambassador inquired how the people themselves would accept the new order of things.

The general stated that a majority of the people, primarily excepting a few hundred old women, were in favor of it; that they soon would be accustomed to not having priests lead all social and cultural activity; and that sunday religious services would be replaced by cultural services, by social entertainment, esthetic [sic] performances and lectures. Further, he said that temperance would be encouraged, without, however, using radical methods. ${ }^{10}$

Presumably Calles was no longer in favor of shooting the town drunk.

The secretary who accompanied Daniels to the interview and who wrote the report quoted is candid in stating that, "No attempt has been made to quote directly the remarks of either the Ambassador or General Calles."ll The memorandum is summary. Yet there can be no doubt that the views of calles

${ }^{10}$ Franklin D. Roosevelt Library. PSF 43, Josephus Daniels, "Letter to Roosevelt," November 5, 1934.

11ibid. 
are accurately given. Calles wanted and intended to found a national church. This is not the opinion of Bailey, sedano, and the present writer only. It was also the opinion of Avlaro obregón.

In a letter date April 7, 1925, about three weeks after Calles had closed La Soledad and given Corpus Christi to Pérez, Obregón discusses "my new point of view concerning the appearance of the schismatic religious movement recently begun in our nation."12 He begins by reviewing briefly the growth of his and Calles' Liberal party and the decline of the Conservatives since the outbreak of "the most recent civil war begun in 1910 by Don Francisco I. Madero and which currently in 1924 is drawing to a conclusion." ${ }^{13}$ Then speaks directly to the matter of the schismatic movement which he considers a grave threat to the Liberal Party.

The schismatic movement in the form and goals which it has shaped for itself constitutes a dangerous experiment the consequences of which are not easily grasped. Existing as it does in our country only as an organization the constituents of which are unable, by the precepts of their own faith to debate whether to follow the conditions of their spiritual vassalage, it is surely not possible to produce a schism within that group in order to divide it into two groups and to have a confrontation between them. It would, therefore, be necessary to improvise a pseudo-Catholic party of such a large size that it would be able to impress public opinion. And that could come about only by drawing elements from the Liberal Party under the

${ }^{12}$ Plutarco Elías Calles, Plutarco Elías Calles Corresponcia Personal (1919-1945). (Mêxico: Fundo de Cultura Económico, 1991), p. 173.

${ }^{13}$ ibid. 
direction of Party leaders. In the eyes of the nation the number of Catholic would increase, the number of Liberals decrease substantially....14

The threat of losing great numbers would increase; many people would accept a schismatic priest "believing that they would absolve themselves of all errors by embracing the denomination of National Catholics." ${ }^{25}$ Creating such a denomination would cause great consternation among the people before the schismatic movement Socialism and Catholicism were considered incompatible. This would not be the only result injurious to the Liberal Party.

A second would be the creation of two distinct, separate, and disparate Catholic parties. One with allegiance to Rome, the other to the national government. This could destroy the Liberal Party. Obregón's argument says that since the existing Conservative Party has always been rooted in the Roman Catholic Church, they are virtually one entity. They would not be harmed by a successful schism in the Church. If a new political entity of any significance is to be created

The schismatic movement as it presently exists is able to achieve the resultant disaster only if it can increase the number of its adherents with enough followers to give substance to its movement and thereby create a national Catholicism which would almost surely destroy the Liberal Party. There would remain only some few routed Liberals who would not have accepted the ruse. Then instead of one Catholic Party which has caused so many evils in this nation to confront the liberal party, there would be two Catholic parties although with

\footnotetext{
${ }^{14}$ ibid.

${ }^{15}$ ibid., p. 174 .
} 
distinct areas of influence. With almost identical formulas they would propagate the same vices and operate within the same set of silly beliefs, and the only dispute which would remain between them would be the dilemma of depending upon a Roman or a national clergy. ${ }^{16}$

This is a political document. In addition to what has been quoted above, Obregón warns Calles of Liberal-Schismatic Catholics leading their " fellow-religionists" astray. He further warns of the confusion which could arise if some of these persons are also seen genuflecting before a priest, albeit a schismatic. Obregón does not write of a schismatic church, but a schismatic priest certainly implies one. As does the entire letter. Furthermore, while he does not state it directly, it is clear that obregón believed that calles was backing a schismatic church. If he had not, he would not have written Calles asking him to cease activities in behalf of the schismatics.

It must be understood at this point that calles and Obregón were such close political allies that the former, as successor to the latter, was later to amend the Constitution so that Obregón could serve a second term as President. This was a direct contradiction to one of the most fundamental tenets of the men who wrote the Constitution of 1917 . One with which Calles used to end much of his personal correspondence: Sufragio Efectivo. No Reelección.

Thus in mid-April General Calles initial attack on the 
Roman Catholic Church had achieved only a slight victory. He had taken one building away from the Roman Catholics, closed it, and given another building to the schismatics. He had indicated clearly by this action that his government would look favorably upon a new sect whose first political loyalty would be to the government in Mexico City, not the one in the Vatican. Plutarco Elías Calles as President of the Republic would help found a state church.

It must have been clear to him, however, that his direct attack on the church buildings and his attempt to have his own priests take command of them had been far from a complete rout of the Catholics. The laity of the Church did not accept the schismatic priests, one of whom, significantly the spaniard, had defected. Blood had been shed and people had died. One of his closest political allies, no friend of the Church himself, strongly advised Calles to stop helping the schismatics.

These facts did not deter General Calles from his objective. Since frontal assault had not achieved his objective, he would try a flanking manoeuvre. He would enforce strictly all the articles of the Constitution designed to limit the ability of the Church to function, especially Article 3 for which he created a special law. 
CHAPTER IX

THE ASSAULT ON THE SCHOOLS : 1926

The first skirmishes between the government of General President Calles and the Roman Catholics in Mexico occurred early in the spring of 1925. The events surrounding Joaquín Pérez Burdar and his failure to establish a national church indicated that the Church could shortly be in another conflict with the Federal Government. The fact that Burdar was supported by Calles indicated that such a conflict was likely to occur. As we have seen, Calles was not a man who was easily deterred from an objective once he had made up his mind.

It was apparent from the outset of the confrontation that neither the state nor the Church wanted the sort of struggle in which people would be killed. As the year progressed, however, there were some signs that, from the Church's point of view, the situation was deteriorating. In July the state of Jalisco closed two seminaries which caused an outbreak of street violence. In August the legislature in the state of Chihuahua fired two employees of the state because they were members of the Knights of Columbus. A federal judge in Ciudad Juarez ordered an orphanage and a home for the aged which were both operated by religious orders placed under the control of the government.

Also in August, Calles made a significant change in his cabinet: he replaced Gilberto Valenzuela as his 
secretary of gobernación with Adalberto Tejeda. Valenzuela had been considered relatively evenminded[sic] on the religious question; Tejada was known to be adamantly anticlerical. Lagarde [the French chargé] described Tejada as "one of the most implacable and malignant enemies of the Catholic religion." 1

The last fact could not, one suspects, have escaped the notice of Calles. Gobernación also had control of all property which had formerly belonged to the Church as calles well knew having been secretary of that office himself. These properties included the schools. There was a further step necessary before calles could begin his new attack.

As shown above, no article of the constitution could be enforced without a ley reglamentaria. For many of the constitutional articles, including two discussed in this paper, 130 and 3, no such leyes had been enacted. Article 33, for example, could easily be enforced because the penalty was written into the article itself. Calles could expel all the foreign clergy and members of religious orders. He needed new legislation to enforce the other articles. Late in 1925 he got it. Just before adjourning for a long recess, the Congress granted to the President special legal powers to reform the penal code. This law was not aimed specifically at the Church and technically was in force only in the Federal District. The two laws which Calles promulgated in the summer of 1926 were, however, aimed directly at the church and were regarded as in force in many of the states of the Mexican Republic.

${ }^{1}$ Bailey, Viva Cristo Rey, p. 50. 
The first of these laws, later to be known as the "Calles Law," though signed on June 14, was not published until July 2 , and was not to take effect until July $31 .{ }^{2}$ There are thirty-three sections to this law. Eleven of them, 23-33, charge the states and local authorities with enforcing them and the constitutional articles to which they pertain. Thirteen of them deal with church property, the registration and nationality of clergy, and their legal activities. The remaining nine deal with education. Put in another fashion: the sections of the Calles Law which deal with education make up a far greater percentage of that law than any other single area covered. One can conclude, therefore, that education was of primary importance in this law. Specific examples must be examined to see this clearly.

The first section of this law which deals with education is, not surprisingly, section three. In this section it is required that primary, elementary, and superior (secondary) education will be the same in both public and private schools. Section four states that no religious corporation nor any minister of any denomination can direct a primary school. Section five places all private primary schools under the control of the State. Section six attacks religious education in two ways: a person may not take a perpetual vow for

${ }^{2}$ El Diario, (Mexico City), 2 July, 1926. it is a standard practice for the large metropolitan newspapers of Mexico to print completely the text of any new and significant law. All quotations and references to the Calles Law are taken from the source in this note. 
educational reasons and it also outlaws religious orders. ${ }^{3}$ Religious orders which relied on persons who took religious vows were, at that time, the only source of teachers for the Catholic schools. Section seven prohibits recruiting youngsters for religious orders. Section twenty-two says that all buildings which had belonged to the Church would hereafter belong to the Nation, and the Nation would determine how they would be used. Buildings which are designed to house schools are rarely good for any other purpose. The state governments needed school buildings. Section twelve is a rather special section.

It states in very clear terms that no official recognition will be given by the state for any "course of studies completed in institutions which are designated for the education of ministers of religion." Article 4 of the Constitution says that each state shall determine the qualifications for a profession. The Calles Law says that education for the ministry shall not be recognized. The effect of this law is, then, threefold: 1) The State will determine how church buildings will be used. 2) It will also determine who can minister in these buildings. 3) Control of both Church property and the qualifications of those who can this use property is very close to establishing an organization which is, de facto, an agency of the state. In this case, a state

${ }^{3}$ In the Roman Catholic Church monastic vows are not the same as religious vows since there are secular orders. 
Church.

Traditionally the Christian Church of all denominations has provided catechetical education to Her youngsters. Within Roman Catholicism this education had, for many centuries, been conducted in the parish schools. These schools were the font of priests and nuns. If a state controls the physical property of a church and can determine who will minister within a church, the next logical step is to raise a generation of "clergymen" who will be indoctrinated with the ideals of the State. If these ideals, which will be taught by the new generation of clerics, do not coincide with the doctrines of the established Church, then those Church doctrines are headed for oblivion. This is what the second law published on July 23, 1926, was designed to do and what, as we shall see, Calles was sure that it would do. Some of the sections of this law must be quoted completely:

Private schools are those sustained with private funds. They must have laic education. That is, they must not teach, defend, nor attack any religion.

There will be two kinds: A) Those incorporated under the Secretary of Public Education. B) Those not so incorporated. The graduation certificate of the $A$ type school will have the same value as the comparable certificate of the public schools. Certificates from schools of the B type will not.

The Secretary of Public Education must give permission for the establishment of single purpose schools.

Primary schools shall not have rooms, choir rooms, or chapels set aside for religious services. In the class rooms, in the corridors, in the vestibules, in the shops in the gymnasia, and in all other sections of the buildings there shall be no 
displays, pictures, engravings, sculptures, nor objects of a religious nature.

Directors and teachers may not be ministers. ${ }^{4}$

Here, in addition to the sections of the Calles Law mentioned above, is an entire law unto itself which all but destroys religious schools.

The two sections which attempt to spell out the death of the religious schools are the two which deal with the power of the secretary of Public Education to grant a charter for a single purpose, i.e., religious, school. The secretary could, if he chose, withhold a charter. The first makes the graduation certificate of the non-incorporated schools of no value. This fact prohibits holders of this certificate from going on to higher education or from obtaining many jobs and almost all jobs which paid more than subsistence wages. The last article is a clear attempt to remove even the slightest religious influence or referents, the "vicious exercise" or the "damned ideas" mentioned above, from the lives of children, lest the children grow into adults with moral and political views unacceptable to the state. The men who wrote the Constitution of 1917 truly believed that primary education was vital in determining the moral and political beliefs which children would hold when they became adults. General President Calles, at any rate, was trying to insure that the generation which succeeded his would hold beliefs acceptable to his

${ }^{4}$ El Universal, (Mexico City), 22 July, 1926. All quotations and refernces to this law were from this source. 
generation. He had captured the schools to insure that they would. Thus, if a new generation is to have only those views acceptable to the state, there will be no need for the Church as She now exists. She will be supplanted. And that is exactly what Calles believed would happen. ${ }^{5}$ The final question is, of course, did he succeed? Or, put another way, did he win the war? This can be answered, of course, only if one regards events subsequent to the to the time when the two laws were issued and Calles began to rigorously enforce the Constitution. 


\section{CHAPTER $\mathrm{X}$}

\section{THE WAR BEGINS}

As a result of the attempts by Calles to enforce the articles and the laws pertaining to religion, a meeting between Calles and a committee representing the National Episcopate of Mexico was arranged. The meeting was held in Chapultepec Castle, August 21, 1926, about three weeks after the Calles Laws took effect. There is a stenographic record of what was said by all the participants. It is a dialogue, but one in which, unfortunately, the nuances of sound and voice cannot be known. And while there are many words in the twelve pages of printed dialogue, the content can be summarized in a brief exchange which took place early in the interview. Calles had earlier established the official position of the state.

With respect to the question of the registration of the priests, I want to make it clear that it is not just a question of numbers. Fundamentally it arises from the fact that in the constitution of the Republic it is established that church buildings are the property of the Nation. Can the legal representative of the people, which is what the government is, demand less than to know who are the persons administering these properties?

The question of dogma or doctrine does not interest the government. Catholics, within their own buildings and without showing disrespect for the legal precepts, may do whatever they please. And speaking of the law, while $I$ am at the head of the Executive Power of the Nation, it will be fulfilled. [emphasis mine] The only way for these difficulties to end is for the clergy to submit to 
the law. ${ }^{1}$

Later in the dialogue.

Bishop of Michoacán: [Then] we must submit ourselves in order not to incur difficulties and not to deprive the faithful of the right they have to worship.

Calles: In what way is worship impeded?

Bishop of Michoacán: From the moment at which we submit to a law, despite the fact that our consciences prohibit us from it.

Calles: It is beyond question that you must submit. Bishop of Michoacán: That is against the dictates of our conscience.

Calles: Above the dictates of conscience there is the law. ${ }^{2}$

In a later exchange on conscience and principles:

Bishop of Tabasco: We have already made it clear with all sincerity that it is not a question of self interest. We are prepared to sacrifice everything save our principles.

Calles: You will not sacrifice your principles, but you want us to sacrifice ours. ${ }^{3}$

And there can be no question of Calles personal ideas in this matter.

${ }^{1}$ Plutarco E. Calles, Pensamiento politico y social, Antologia (1913-1936), (México: Fondo de Cultura Económico, 1988), p. 134 .

${ }^{2}$ ibid., p. 190.

${ }^{3}$ ibid. 
But I am not the one who is going to resolve this business. It is a matter for the Congress, and with all sincerity I tell you that I am in perfect accord with what the law you are trying to change says, since it agrees with my own political and philosophical convictions. ${ }^{4}$

In his final words to the bishops Calles says much the same thing he said in the beginning: "As long as the Catholics remain within their churches and the law, they may do rather much what they please. The government cares nothing for dogma nor doctrine." 5

The dialogue ended where it had begun. The bishops declared that the state had in fact interfered with Her spiritual mission. With some bishops dissenting, the Roman Catholic Episcopate of Mexico suspended the liturgy of all the sacraments of the Roman Catholic Church in the Republic of Mexico. On August 1, 1926, for the first time in over fourhundred years no eucharist was celebrated on Mexican soil.

Calles and the men around him welcomed both the interdiction and the war which followed. They apparently saw it as a means of achieving their goal of ridding Mexico of the Roman Catholic Church.

I believe we have reached the moment when the lines of battle are definitely drawn; the hour is approaching for the decisive battle; we will see whether the Revolution has triumphed over reaction or whether the victory of the

${ }^{4}$ ibid., p. 178 .

5ibid., p. 193. 
revolution has been ephemeral. ${ }^{6}$

"President Calles has decided this time to go the whole hog and force a complete cessation of religious cult through the country, calculating as he told his friends, that if once the habit of church-going could be broken, the Indians would forget it." The words of this British diplomat, who held his appointment in Mexico City in 1926, described correctly the intentions of the government. ${ }^{7}$

Lagarde said that Calles told him:

Every week that passes without religious services will lose the Catholic religion about 2 per cent of its faithful... He had decided to finish with the Church and to rid his country of it, once and for all. [emphasis mine] At times, President Calles, despite his realism and his coldness, gave the impression... of approaching the religious question in an apocalyptic and mystic spirit. ${ }^{8}$

Tejeda, Calles' Secretaria de Gobernación, was not to be outdone in anticlerical rhetoric:

The Church has exceeded our wildest hopes in decreeing the suspension of religious services, nothing could be more pleasing to us... We have got the clergy by the throat and will do everything to strangle it. ${ }^{9}$

Jean Meyer has put the argument even more succinctly: "The Government's argument was simple: religion was part of the state, and the Church with it; everything, therefore, must be subjected to regulation by the state."10

${ }^{5}$ Meyer, La Cristiada, p. 44.

${ }^{7}$ ibid.

${ }^{8}$ ibid.

'ibid.

${ }^{10}$ ibid. 
- Oد TุXəW

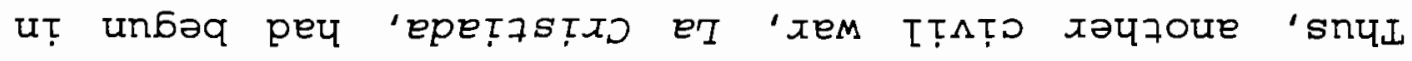
$\angle Z T$ 


\section{Bibliography \\ Books}

Bailey, David C. Viva Cristo Rey: The Cristero Rebellion and the Church-State Conflict in Mexico. Austin and London: University Texas Press, 1974.

Beltran, Lauro Lopez. La Persecución Religiosa en México. México: Tradición, 1987.

Calles, Plutarco Elías. Plutarco Elías Calles Corresponcia Personal (1919-1945. Fondo de Cultura Económico, México, 1991.

- Plutarco Elías Calles Pensamiento político $y$ social, Antología (1913-1936). Fondo de Cultura Económico, México, 1988.

Campos Moises Ochoa. Calles el estadista. Editorial Trillas, México, 1976.

Carpizo, Jorge. La Constitutión Méxicana de 1917. Universidad Nacional Autonoma de México, México, 1979.

Cassillas, José Guiterez. Historia de la Iglesia en México. Editorial Porrua, S.A., México, 1974.

del Rio, Salvador. Los Presidentes de México Revolución y Posrevolución. Editoria Everest Méxicana, S.A., México, 1982 .

Diarios de los Debates del Congreso Constityuente. Imprenta de la Camara de Diputados, México, 1922. de Cultura Economica, México, 1987.

Dragon, Antonio, S.J. Vida Intima del Padre Pio. Figueras y Epidosdio de las Historia de Mexico Editorial Jus, S.A. Mexico, 1929.

Flores, Jesus Romero. Don Miquel y Costilla: Padre de la Independencia Mexicana. Editions Botas, México, 1953.

Hale, Charles C. Mexican Liberalism in the Age of Mora, $1821-$ 1853. Yale University Press, New Haven, 1968.

Iglesias, Eduardo, and del Campo, Rafael Martinez [Moctezuma, Aquiles P.]. El Conflicto Reliqioso de 1926: Sus Origenes 
su Desarrollo, su Solución. Figueras y Episodio de la Historia de Mexico Editorial Jus, Mexico, 1929.

Knight, Alan. The Mexican Revolution. University of Nebraska Press, Lincoln, 1986.

Krauze, Enrique. Reformar desde el origen Plutarco E. Calles. Fondo de Cultura Económico, México, 1987.

Larin, Nicolás. La Rebeliónde los Cristero1926-1929. Translated by Angel Tomás. Ediciones ERA, México, 1968.

Meyer, Jean. La Cristiada, 3 vols. Translated by Aurelio Garzón del Camino. México, Siglo Veintiuno Editores, 1973 .

Dopesá, La Revolution Mejicana, 1910-1940. Barcelona:

Palavicini, Felix I. Historia de la Constitutión de 1917, 2 vols. Gobierno del Estado de Querérato, México, 1987.

Quirk, Robert $\mathrm{E}$. The Mexican Revolution and the Catholic Church 1910-1929. Bloomington and London: Indiana University Press, 1973.

Ramirez, Felipe Tena. Leyes Fundamentales de México 1808-1987. México: Editorial Porrúa, 1987.

Sedano, Alicia Olivera. Aspectos del Conflicto Religioso de 1926 a 1929: Sus Antecedents y Consequencias. México: Secretaria de Educatión Pública, 1987.

White, Jon M. Cortés and the Downfall of the Aztec Empire. Carroll\&Graf Publishers, New York, 1971.

\section{Articles}

Arciniega, Víctor Díaz. Historia Mexicana. March 30, 1985, p. 460 .

Arostegui, Adrian A. Bantjes. "Religión y Revolución en México, 1929-1940." Boletín, Enero 1994.

Barragán Rodriguez, Juan. "Historia del Ejêrcito y de la Revolución Constitucionalista". cited in Cronica Ilustrada Revolución Mexicana, Octber 4, 1967.

\section{Documents}

Constitución Política de Los Estados Unidos Mexicanos. Editorial Porrúa, S.A. México, 1992. 
Newspapers

1 El Diario Official, 2 Julio 1926.

2 El Universial, 22 Julio 1926. 